\title{
Factors Influencing the Use of Booster Seats: A Statewide Survey of Parents
}

C. Raymond Bingham

David W. Eby

Heather M. Hockanson

Arlene I. Greenspan

April 2005
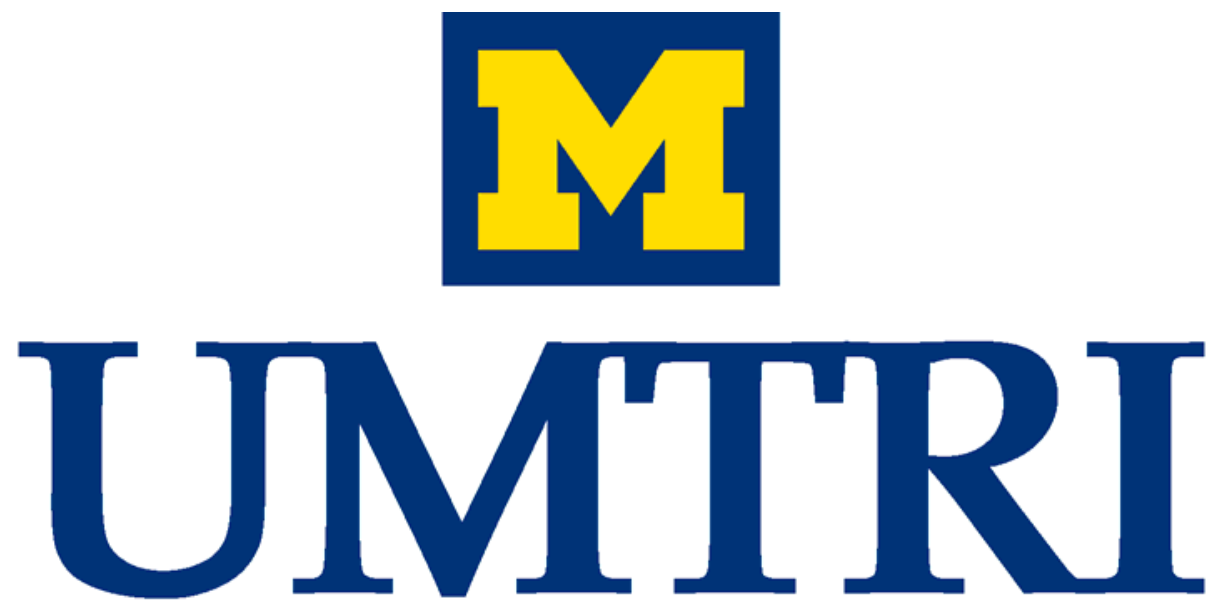

Factors Influencing the Use of Booster Seats:

A Statewide Survey of Parents

\author{
C. Raymond Bingham \\ David W. Eby \\ Heather M. Hockanson \\ Arlene I. Greenspan
}

The University of Michigan

Transportation Research Institute

Ann Arbor, MI 48109-2150

U.S.A.

April 2005 
Technical Report Documentation Page

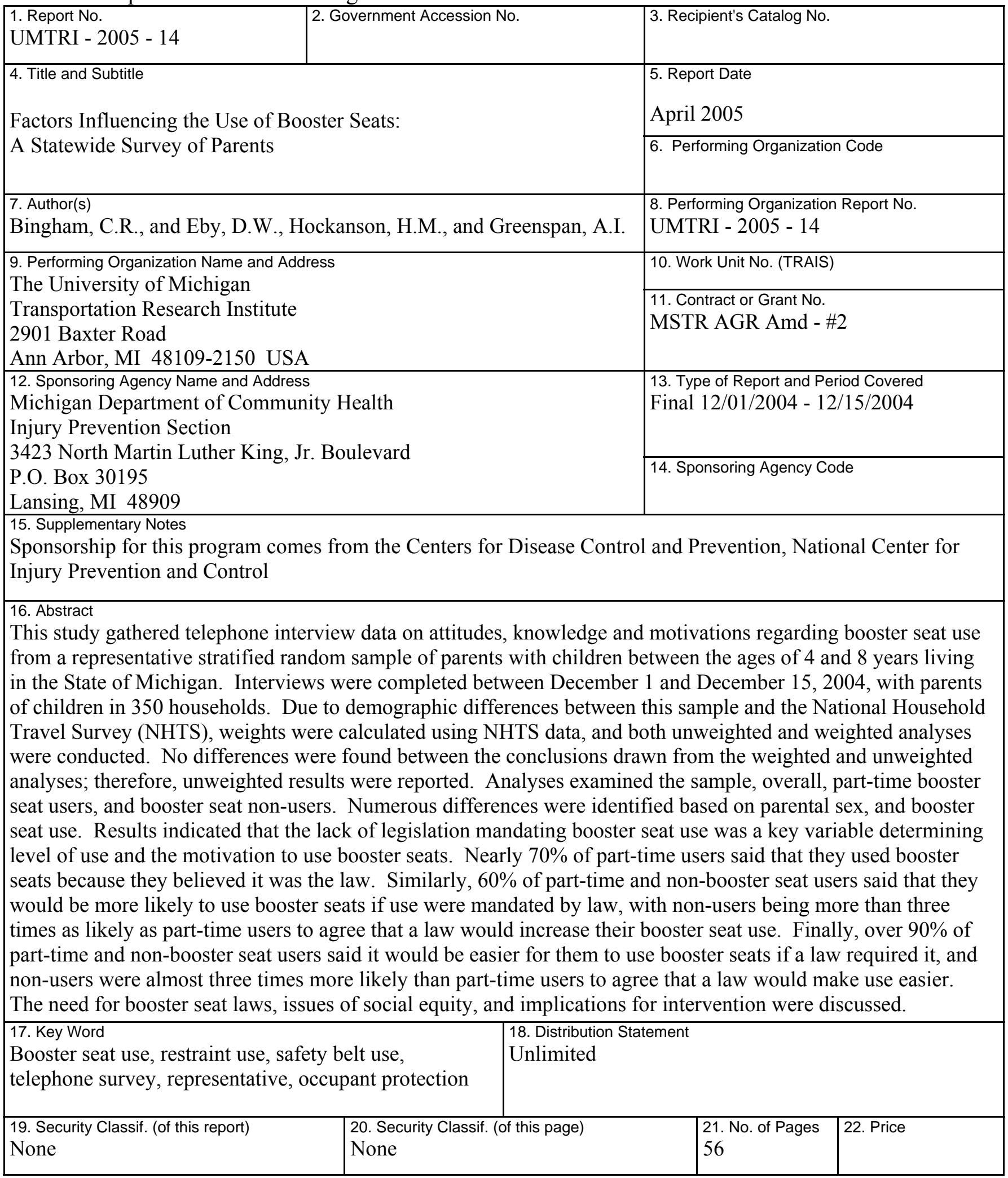




\section{SI* (MODERN METRIC) CONVERSION FACTORS}

APPROXIMATE CONVERSIONS TO SI UNITS

\begin{tabular}{|c|c|c|c|c|}
\hline Symbol & When You Know & Multiply By & To Find & Symbol \\
\hline \multicolumn{5}{|c|}{ LENGTH } \\
\hline in & inches & 25.4 & millimeters & $\mathrm{mm}$ \\
\hline $\mathrm{ft}$ & feet & 0.305 & meters & $\mathrm{m}$ \\
\hline yd & yards & 0.914 & meters & $\mathrm{m}$ \\
\hline $\mathrm{mi}$ & miles & 1.61 & kilometers & $\mathrm{km}$ \\
\hline \multicolumn{5}{|c|}{ AREA } \\
\hline$i n^{2}$ & square inches & 645.2 & square millimeters & $\mathrm{mm}^{2}$ \\
\hline $\mathrm{ft}^{2}$ & square feet & 0.093 & square meters & $\mathrm{m}^{2}$ \\
\hline $\mathrm{yd}^{2}$ & square yard & 0.836 & square meters & $\mathrm{m}^{2}$ \\
\hline ac & acres & 0.405 & hectares & ha \\
\hline $\mathrm{mi}^{2}$ & square miles & 2.59 & square kilometers & $\mathrm{km}^{2}$ \\
\hline \multicolumn{5}{|c|}{ VOLUME } \\
\hline $\mathrm{fl} \mathrm{oz}$ & fluid ounces & 29.57 & milliliters & $\mathrm{mL}$ \\
\hline gal & gallons & 3.785 & liters & $\mathrm{L}$ \\
\hline $\mathrm{ft}^{3}$ & cubic feet & 0.028 & cubic meters & $\mathrm{m}^{3}$ \\
\hline $\mathrm{yd}^{3}$ & cubic yards & 0.765 & cubic meters & $\mathrm{m}^{3}$ \\
\hline \multicolumn{5}{|c|}{ NOTE: volumes greater than $1000 \mathrm{~L}$ shall be shown in $\mathrm{m}^{3}$} \\
\hline \multicolumn{5}{|c|}{ MASS } \\
\hline $\mathrm{Oz}$ & ounces & 28.35 & grams & g \\
\hline $\mathrm{lb}$ & pounds & 0.454 & kilograms & $\mathrm{kg}$ \\
\hline $\mathrm{T}$ & short tons $(2000 \mathrm{lb})$ & 0.907 & megagrams (or "metric ton") & $\mathrm{Mg}$ (or "t") \\
\hline \multicolumn{5}{|c|}{ TEMPERATURE (exact degrees) } \\
\hline${ }^{\circ} \mathrm{F}$ & Fahrenheit & $\begin{array}{l}5(\mathrm{~F}-32) / 9 \\
\text { or }(\mathrm{F}-32) / 1\end{array}$ & Celsius & ${ }^{\circ} \mathrm{C}$ \\
\hline \multicolumn{5}{|c|}{ ILLUMINATION } \\
\hline fc & foot-candles & 10.76 & & Ix \\
\hline $\mathrm{fl}$ & foot-Lamberts & 3.426 & candela $/ \mathrm{m}^{2}$ & $\mathrm{~cd} / \mathrm{m}^{2}$ \\
\hline \multicolumn{5}{|c|}{ FORCE and PRESSURE or STRESS } \\
\hline lbf & poundforce & 4.45 & newtons & $\mathrm{N}$ \\
\hline lbf/in ${ }^{2}$ & poundforce per square inch & 6.89 & kilopascals & $\mathrm{kPa}$ \\
\hline
\end{tabular}

\begin{tabular}{|c|c|c|c|c|}
\hline \multicolumn{5}{|c|}{ APPROXIMATE CONVERSIONS FROM SI UNITS } \\
\hline Symbol & When You Know & Multiply By & To Find & Symbol \\
\hline \multicolumn{5}{|c|}{ LENGTH } \\
\hline $\mathrm{mm}$ & millimeters & 0.039 & inches & in \\
\hline $\mathrm{m}$ & meters & 3.28 & feet & $\mathrm{ft}$ \\
\hline $\mathrm{m}$ & meters & 1.09 & yards & $y d$ \\
\hline $\mathrm{km}$ & kilometers & 0.621 & miles & $\mathrm{mi}$ \\
\hline \multicolumn{5}{|c|}{ AREA } \\
\hline $\mathrm{mm}^{2}$ & square millimeters & 0.0016 & square inches & $i^{2}$ \\
\hline $\mathrm{m}^{2}$ & square meters & 10.764 & square feet & $\mathrm{ft}^{2}$ \\
\hline $\mathrm{m}^{2}$ & square meters & 1.195 & square yards & $y d^{2}$ \\
\hline ha & hectares & 2.47 & acres & ac \\
\hline $\mathrm{km}^{2}$ & square kilometers & 0.386 & square miles & $\mathrm{mi}^{2}$ \\
\hline \multicolumn{5}{|c|}{ VOLUME } \\
\hline $\mathrm{mL}$ & milliliters & 0.034 & fluid ounces & $\mathrm{fl} \mathrm{oz}$ \\
\hline $\mathrm{L}$ & liters & 0.264 & gallons & gal \\
\hline $\mathrm{m}^{3}$ & cubic meters & 35.314 & cubic feet & $\mathrm{ft}^{3}$ \\
\hline$m^{3}$ & cubic meters & 1.307 & cubic yards & $y d^{3}$ \\
\hline \multicolumn{5}{|c|}{ MASS } \\
\hline $\mathrm{g}$ & grams & 0.035 & ounces & $\mathrm{oz}$ \\
\hline $\mathrm{kg}$ & kilograms & 2.202 & pounds & lb \\
\hline Mg (or "t") & megagrams (or "metric ton") & 1.103 & short tons (2000 lb) & $\mathrm{T}$ \\
\hline \multicolumn{5}{|c|}{ TEMPERATURE (exact degrees) } \\
\hline${ }^{\circ} \mathrm{C}$ & Celsius & $1.8 \mathrm{C}+32$ & Fahrenheit & ${ }^{\circ} \mathrm{F}$ \\
\hline \multicolumn{5}{|c|}{ ILLUMINATION } \\
\hline Ix & $\operatorname{lux}$ & 0.0929 & foot-candles & fc \\
\hline $\mathrm{cd} / \mathrm{m}^{2}$ & candela $/ \mathrm{m}^{2}$ & 0.2919 & foot-Lamberts & $\mathrm{fl}$ \\
\hline \multicolumn{5}{|c|}{ FORCE and PRESSURE or STRESS } \\
\hline N & newtons & 0.225 & poundforce & \\
\hline $\mathrm{kPa}$ & kilopascals & 0.145 & poundforce per square inch & $\mathrm{lbf} / \mathrm{in}^{2}$ \\
\hline
\end{tabular}

*SI is the symbol for the International System of Units. Appropriate rounding should be made to comply with Section 4 of ASTM E380. (Revised March 2003) 


\section{Contents}

Title Page

Technical Report Documentation Page .......................................................... iii

SI (Modern Metric) Conversion Factors ............................................................ v

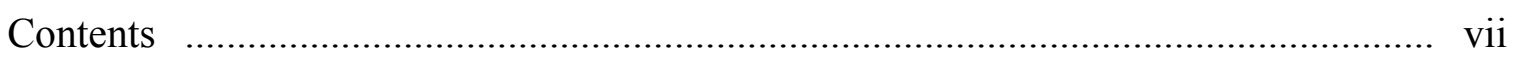

List of Figures

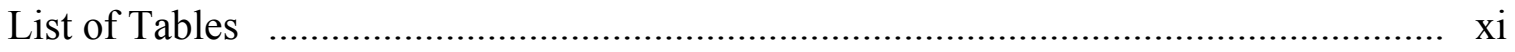

List of Abbreviations and Symbols ................................................................... xiii

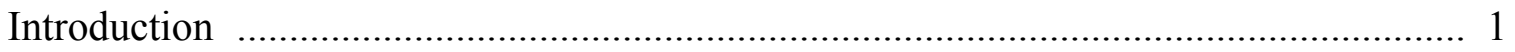

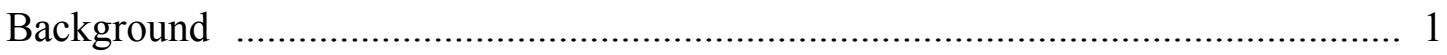

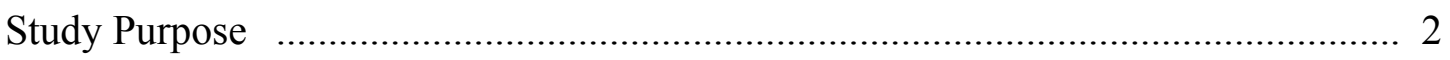

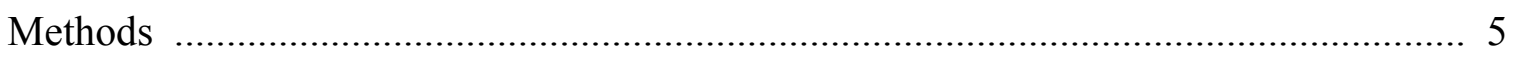

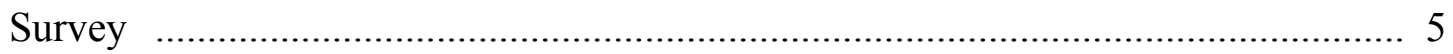

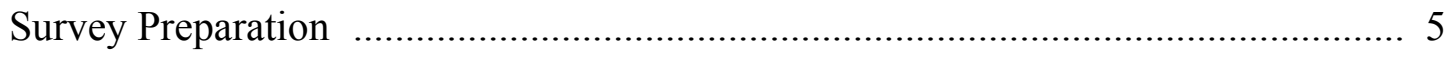

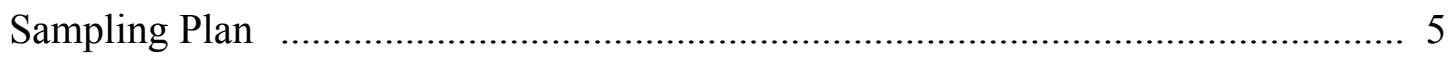

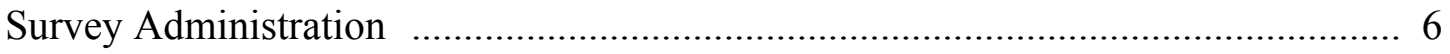

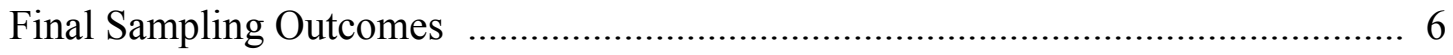

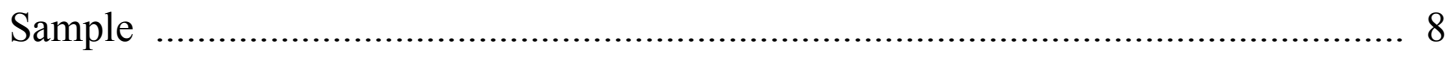

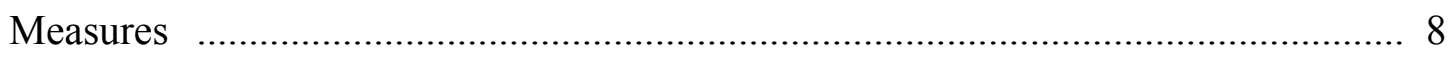

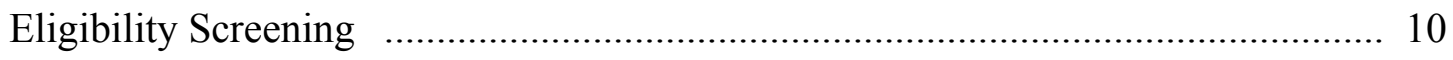

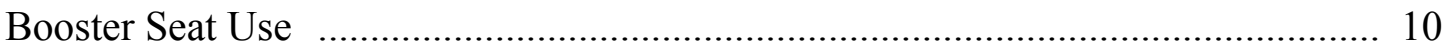

Conditions when Booster Seats are Used f.................................................. 10

Reasons for Booster Seat Use ................................................................... 10

Awareness of Booster Seat Safety and Regulations ........................................ 10

Reasons for Booster Seat Use and Non-Use .................................................... 11 
Make Booster Seat Use Easier ………………………........................................ 11

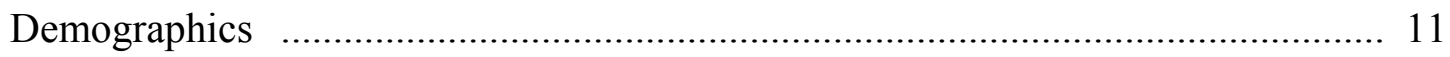

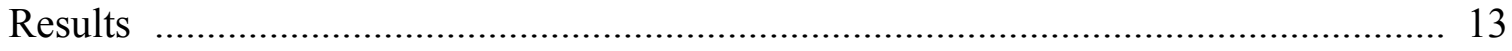

Overview of Entire Sample ………………………….................................... 13

Part-Time Booster Seat Users ............................................................................ 14

Booster Seat Use by Driving Condition ………………...................................... 14

Motivations to Use Booster Seats ……………………………............................ 17

Part-Time and Non-Booster Seat Users ............................................................ 19

Knowledge and Opinions .................................................................................. 19

Reasons for Not Using Booster Seats ............................................................... 22

Reasons for Using Booster Seats ……………………..................................... 23

Making Booster Seat Use Easier ...................................................................... 24

Multivariate Model Testing ............................................................................ 25

Never, Part-Time and Always Use …………………................................... 25

Part-Time Versus Non-Users ........................................................................... 27

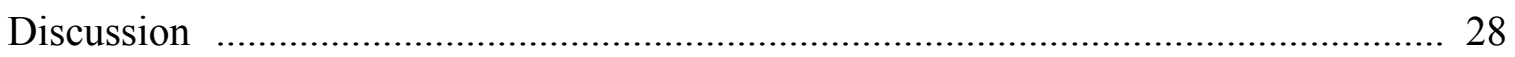

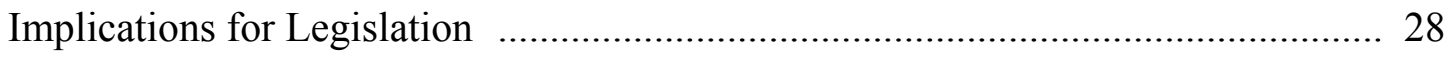

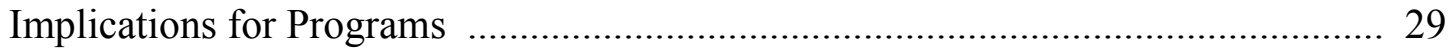

Direct Observation Versus Surveys ...................................................................... 31

Appendix A - Telephone Survey ...………………………………………….... 33

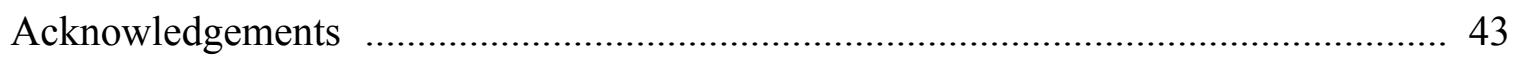

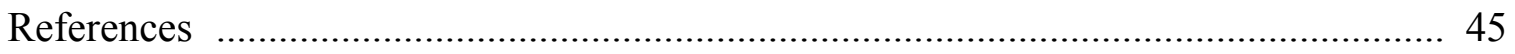




\section{List of Figures}

Figure 1. Percent booster seat use overall, and for men and women in various driving situations ………………………….................................. 17

Figure 2. Motivations for using booster seats by sex ............................................... 18

Figure 3. Percent responding "True" by sex ……………………………………..... 20

Figure 4. Percent responding "True" by never versus part-time use ............................ 21

Figure 5. Percent endorsement of reasons for booster seat non-use by sex .................. 22

Figure 6. Percent endorsement of reasons for booster seat non-use by part-time versus never use …………………………........................................ 23

Figure 7. What would make booster seat use easier by sex ........................................ 25

Figure 8. What would make booster seat use easier by use group ............................... 26 


\section{List of Tables}

Table 1. Sampling areas and numbers of participants sampled ................................. 6

Table 2: Sample disposition for UMTRI stakeholder booster seat survey $\quad$.................... 7

Table 3. Demographic data for the study sample $\quad$....................................................... 9

Table 4. Booster seat use, booster-aged, and vehicle type ...................................... 14

Table 5. Description of participants by their self-reported booster seat use $\ldots . . \ldots \ldots \ldots . . . . .15$

Table 6. Driving circumstances when booster seats are always used, by sex $\quad$.............. 18

Table 7. Reasons for using a booster seat ….......................................................... 19

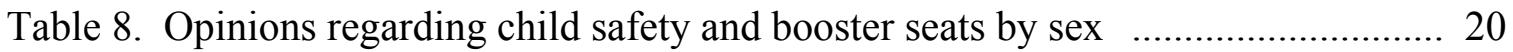

Table 9. Opinions regarding child safety and booster seats by booster

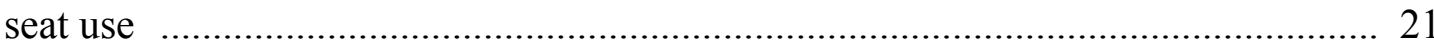

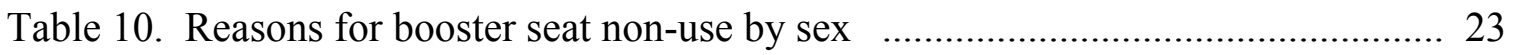

Table 11. Reasons for booster seat non-use by use group ..................................... 24

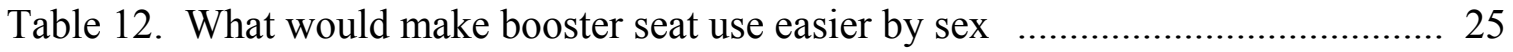

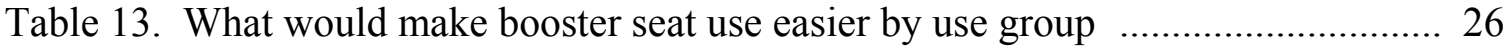

Table 14. Association between never using booster seats and reasons for non-use 


\section{List of Abbreviations and Symbols}

$\mathrm{MDCH}$

$\mathrm{CDC}$

NCIPC

NHTS

Crash

NHTSA

National Highway Traffic Safety Administration

RDD

Random Digit Dialing

MSA

Metropolitan Statistical Area

Eligible children

4-to-8-year-old children 
xiv 


\section{Introduction}

\section{Background}

It is widely recognized in the fields of injury prevention and transportation safety that motor vehicle crash (crash) is the leading cause of morbidity and mortality among children ages 4 to 8 years (Subrmanian, 2005). Although motor-vehicle-related injuries have declined in recent years (National Highway Traffic Safety

Administration [NHTSA], 2003a), child restraint non-use is common in this age group, and contributes significantly to the risk of crash-related injury. Booster seats are important and effective tools in the effort to protect young children from injury in crashes, decreasing the risk of injury in a crash by as much as 59\% (Durbin, Elliot, Winston, 2003; Nance et. al., 2004).

In spite of their effectiveness (Durbin, Kallan, Winston, 2001), children who have outgrown child safety seats (i.e., infant or toddler seats) but are still too small to be fully protected by a safety belt designed for an adult (adult safety belt, i.e., lap and shoulder), are often either not placed in booster seats, placed inappropriately in a safety belt, or not restrained at all. More than $50 \%$ of children killed in crashes in 2003 were completely unrestrained, and between $50 \%$ and $95 \%$ of children aged 4 to 8 were inappropriately placed in safety belts (Decina, Knoebel, 1997; Durbin et. al., 2003; Eby, Molnar, Olk, 2000; NHTSA, 2003b).

Rather than providing protection from injury during a crash, safety belts can increase the risk of injury to 4-to-8-year-old children. Compared to children placed in booster seats, those restrained with a safety belt are 3.5 times more likely to suffer a significant injury and 4.2 times more likely to suffer a significant head trauma in a crash (Winston, Durbin, Kallan, Moll, 2000). Adult safety belts are designed to fit and protect individuals with typical adult stature. When children are restrained in a three-point safety belt system, the lap belt tends to be positioned above the pelvis where the force of a crash can cause severe internal injuries to the abdominal area. Children who are 4 to 8 years of age also tend to be too short for the shoulder belt, resulting in the shoulder belt being positioned across the neck or lower face rather than across the more rigid structures of the chest and clavicle. With this improper positioning, the force of a motor vehicle crash can cause severe neck and face injuries. Because the improper positioning of the shoulder belt is uncomfortable, many children (or their parents) will place the shoulder belt under the arm or behind the back. In this case the force of a crash can cause the child's body to bend sharply at the waist where the head often contacts the knees leading to severe head injury. Safety belt positioning booster seats are designed to compensate for children's small body sizes by raising them up relative to the angle of the safety belt so that both the lap and shoulder belts fit the child passengers' hips, chests, and necks appropriately.

Given the unquestionable safety benefits, NHTSA (2005) recommends that children be placed in booster seats when they have grown too large to be restrained safely in a child safety seat. However, as already observed, rates of booster seat use are generally low (Durbin, et al., 2003; Decina, Knoebel, 1997; Ebel, Koepsell, Bennett, 
Rivara, 2003; Ramsey, Simpson, Rivara, 2000; Taft, Mickalide, Taft, 1999). In order to design effective programs to promote use of booster seats it is imperative to understand the barriers to booster seat use as well as the factors that promote use.

Relatively little is known about which factors influence use of booster seats. In a nationwide telephone survey, NHTSA (2004) found that more than 80 percent of parents who had booster-seat-age children were aware of and/or owned booster seats. The study also found that knowledge of when to use a booster seat is poor, with less than one-half of parents knowing that children weighing 40 to 60 pounds should be placed in a booster seat and less than two-thirds having a correct understanding of the child safety restraint laws in their state. Thus, there appears to be significant misunderstanding surrounding the use of booster seats.

Utilizing parental interview methods, a handful of studies has begun to investigate the factors that influence use of booster seats (Ebel et al., 2003; NHTSA, 2004; Ramsey et. al., 2000; Vaca et. al., 2002). Collectively, these studies have found that child safety is the primary reason given by parents for using booster seats. Other common reasons cited were increased child comfort resulting from a proper fit of the threepoint safety belt and that the booster seat allows the child to see outside the car. Commonly cited barriers to booster seat use were: the child does not like it; the child is large enough to be properly protected by an adult safety belt; unavailability of a booster seat; difficulty placing the seat in a particular vehicle; and a belief that booster seats increase the risk of injury in a crash.

\section{Study Purpose}

The purpose of the present study was to further investigate the factors that influence the use and non-use of booster seats by designing, collecting, and analyzing telephone survey data from a representative sample of parents of 4-to-8-year-old children residing in Michigan. The intent was to ascertain the self-reported reasons for use and non-use, knowledge about booster seats and booster seat laws in Michigan, and to find out from parents who were part-time users or non-users of booster seats what factors would motivate them to use booster seats consistently. This study was the first to examine these factors in a representative statewide sample of parents with 4-to-8year-old children.

This study examined telephone survey data from a representative sample of parents of 4-to-8-year-old children residing in Michigan to ascertain their reasons for use and non-use, knowledge about booster seats and booster seat laws in Michigan, and to find out from parents who were part-time users or non-users of booster seats what factors would motivate them to use booster seats consistently.

This study is unique from previous research on child safety restraint use because, while examining knowledge about child safety restraints and reasons for use and nonuse, it is representative of the Michigan population of parents of 4-to-8-year-old children, and because it specifically identified factors that parents indicate would increase their booster seat use. Both of these unique characteristics will increase the 
study's contribution to a greater understanding of booster seat use, and provide important representative information to guide the development and implementation of programs and policies to increase booster seat use. 


\section{METHODS}

\section{Survey}

\section{Survey Preparation}

The survey was developed by the evaluation team with assistance from the project Principal Investigator and members of the Michigan Child Passenger Safety Coalition, formed to provide expert direction for the project program and evaluation staff. Survey items were drafted and shared with the PI and coalition members who suggested additional items and response options, alternative item and response wording, and item consolidations and deletions. Skip patterns contingent on participant response and item applicability were mapped onto the survey. MORPACE International was contracted to conduct the telephone interviews. Further refinements of item wording and skip patterns were made during the process of preparing the survey for administration using Computer Assisted Telephone Interviewing.

\section{Sampling Plan}

The sampling plan was key to the success of this study, which was to interview a representative sample of parents living in Michigan households with children between the ages 4 and 8 years (target households). Target households have a relatively low incidence rate of 18 percent in the population of all Michigan households. Given this incidence rate, it was estimated that approximately 100 telephone numbers would need to be dialed in order to contact one target household if simple random-digit-dialing (RDD) procedures were followed. Such a low success rate was unrealistic; hence, alternative higher-yield methods that would provide a representative sample were explored.

The first method used a concentrated RDD approach. Using available 2003 Claritas census block data, 1,344 Michigan census blocks were identified in which over 25 percent of the households had at least one eligible-aged child. As can be seen from the maps, this concentrated RDD method would select the sample from a small number of geographically clustered Michigan census blocks. The sampling frame resulting from this method would include only 16 percent of all Michigan census blocks, and would systematically exclude target households located across large areas of the state. The result would be an unrepresentative sample.

A second sampling strategy would select a number of households from each block that was proportionate to the percentage of target households in that block. The result would be more recruitment occurring in areas with higher concentrations of target households. However, this approach was also rejected because so many blocks had very low concentrations of target households, resulting in an unacceptable call ratio.

The third sampling approach considered was a hybrid sampling design that would have used RDD to recruit half of the study sample $(n=175)$ from census blocks with 
target household concentrations of at least 20 percent, and recruit the other half of the study sample from census blocks where the incidence of target households was less than 20 percent. This strategy was rejected because when census blocks were translated to telephone exchanges, the percent of households with target children was low for exchanges with large numbers of households.

Ultimately, it was determined that it would be difficult to complete a representative sample of target households no matter what sampling method was used. The selected sampling procedure that was used to recruit the sample for this study used a statewide listing of household telephone numbers within Metropolitan Statistical Areas (MSAs; designated areas based on population densities) to recruit a stratified random sample. The MSA strata were: within city centers of MSAs; outside city centers of MSAs; suburban counties of MSAs; and areas not in an MSA. At the time when recruitment was carried out, MSAs without a city center did not occur in Michigan, and were not used in the sampling plan. Table 1 shows the distribution across the MSA strata of households in the final sample.

Table 1. Sampling areas and numbers of participants sampled

\begin{tabular}{lcr}
\hline Household Density Type & Frequency & Percent \\
\hline In City Center of MSA & 94 & $27 \%$ \\
Outside City Center of MSA & 165 & $47 \%$ \\
Suburban County of MSA & 27 & $8 \%$ \\
Not in an MSA & 64 & $18 \%$ \\
Total Sample & 350 & $100 \%$ \\
\hline
\end{tabular}

\section{Survey Administration}

During the month of December, 2004, interviews were completed with parents and other adult guardians of 4-to-8-year-old children (eligible children) living in 350 households across Michigan. The interview averaged 6.5 minutes in length, and covered the following specific topics:

Number of eligible children and number of available booster seats in the household; overall frequency of booster seat use; primary reasons for booster seat use; frequency of booster seat use under various driving conditions; information sources for booster seat use and acquisition; knowledge about booster seats; factors that would make booster seat use easier; and, demographics. A complete copy of the survey can be found in Appendix A.

\section{Final Sampling Outcomes}

A total of 6,344 telephone numbers were dialed, and a minimum of six attempts to complete the call were made with each number, resulting in one of three final dispositions: (1) eligible contact (E), (2) ineligible contact (IE), and (3) unknown eligibility (UK). Subcategories for each of these dispositions are shown in Table 2. The sample classified as unknown eligibility corresponds to numbers that did not 
receive answers; hence, the eligibility status for telephone numbers in this group is unknown. The final sample outcome for this project is shown in Table 2.

Table 2: Sample disposition for UMTRI stakeholder booster seat survey

\begin{tabular}{lcc}
\hline Sample Category & Frequency & Percent \\
\hline Eligible & 476 & $\mathbf{8 \%}$ \\
Completed Interview & 350 & $6 \%$ \\
Refused & 101 & $2 \%$ \\
Terminated Mid-Survey & 19 & $0 \%$ \\
Language Barrier/Deaf & 6 & $0 \%$ \\
\hline Ineligible & 2,907 & $\mathbf{4 6 \%}$ \\
Not Qualified for Survey & 2,720 & $43 \%$ \\
Disconnected/Business/Wrong Number & 171 & $3 \%$ \\
Fax Machine/Data Line & 16 & $0 \%$ \\
\hline Unknown & 2,961 & $\mathbf{4 7 \%}$ \\
No Answer/Busy & 1,248 & $20 \%$ \\
Answering Machine & 1,217 & $19 \%$ \\
Refused to Start Interview & 322 & $5 \%$ \\
Scheduled for Callback & $\mathbf{6 , 3 4 4}$ & $\mathbf{1 0 0 \%}$ \\
\hline & & $3 \%$ \\
\hline
\end{tabular}

Based on the Council of American Survey Research Organization method of estimating response rates, approximately 14.1 percent of unknown dispositions would have been eligible had contact been made $(E /[E+I E]=476 / 3,383=14.1$ percent $)$. Based on this estimate, the total eligible numbers (TE) were approximately 894 (TE $=$ $[\mathrm{UK} \times 0.141]+\mathrm{E}=[2,961 \times 0.141]+476=894)$. This would result in an adjusted response rate $(A R R)$ of 39.1 percent $(A R R=$ completed interviews $/ \mathrm{TE}=350 / 894=$ 39.1 percent). 


\section{Sample}

Participants in the telephone survey totaled 350 , and were 33 percent male $(n=115)$ and 67 percent female $(n=235$; see Table 1$)$. Respondents included the mothers (65.4 percent), fathers (32.6 percent), step-mothers (.3 percent), step-fathers (.3 percent) and other adult relatives (1.4 percent). Forty percent of the sample graduated college, 18 percent completed at least some post-graduate education, and 42 percent completed less than a 4-year college degree. The large majority of participants were currently married (92 percent), and the majority were white (93 percent), with only 3 percent African American. Thirty-six percent of women and 97 percent of men were employed full-time, and 23 percent of women were employed part-time. Twenty-five percent of the respondents reported a household income between $\$ 35,000$ and $\$ 49,999$ and 42 percent reported household incomes of $\$ 50,000$ or more (see Table $3)$.

Demographic characteristics of the sample were compared with data from the National Household Travel Survey (NHTS) to determine how closely it matched the Michigan population of households with at least one child between the ages of 4 and 8 years. US Census data could not be used because the public data bases have been collapsed across the age-group of interest in this study.

NHTS data were obtained from the NHTS web-site, and were weighted to represent a 100 percent sample of households. Data for Michigan were then used to obtain demographic profiles of Michigan households with eligible children.

Based on the results, the sample for this study differed from the NHTS in the racial composition of households with children between 4 and 8 years of age. NHTS data showed that 79 percent of households were white, 15 percent African American, less than 1 percent Asian, Hispanic/Latino, and multiracial. Other demographic characteristics were highly similar between the NHTS and the sample for this study.

The data from the NHTS were used to calculate post-stratification weights to adjust for differences between the racial distribution of the sample for this study and that for the NHTS. This was achieved using the following calculation:

$$
W_{i j}=\left(\frac{S_{j}}{p_{j}}\right)
$$

where $w_{i j}$ is the weighted value for case $i$ in group $j, S$ is the proportion of the population in group $j$, and $p$ is the sample proportion in group $j$. This weight was entered into the cross-tabulation and logistic models.

\section{Measures}

Following is a description of the measures included in the survey. They are presented by content area and/or purpose. The interview text can be found in Appendix A. 
Table 3. Demographic data for the study sample

\begin{tabular}{|c|c|c|c|c|c|c|}
\hline \multirow[b]{2}{*}{ Measure } & \multicolumn{2}{|c|}{$\begin{array}{l}\text { Overall } \\
(n=350)\end{array}$} & \multicolumn{2}{|c|}{$\begin{array}{l}\text { Women } \\
(n=235)\end{array}$} & \multicolumn{2}{|c|}{$\begin{array}{c}\text { Men } \\
(n=115)\end{array}$} \\
\hline & Count & Percent & Count & Percent & Count & Percent \\
\hline \multicolumn{7}{|l|}{ Who responded } \\
\hline Mother & 229 & 65.4 & 229 & 97.45 & 0 & 0.00 \\
\hline Father & 114 & 32.6 & 0 & 0.00 & 114 & 99.13 \\
\hline Step-mother & 1 & 0.3 & 1 & 0.43 & 0 & 0.00 \\
\hline Step-father & 1 & 0.3 & 0 & 0.00 & 1 & 0.87 \\
\hline Other adult relative & 5 & 1.4 & 5 & 2.13 & 0 & 0.00 \\
\hline \multicolumn{7}{|l|}{ Completed Education } \\
\hline Less than high school & 6 & 1.7 & 3 & 1.28 & 3 & 2.61 \\
\hline High school & 60 & 17.1 & 33 & 14.04 & 27 & 23.48 \\
\hline Some college/ trade school & 82 & 23.4 & 63 & 26.81 & 19 & 16.52 \\
\hline Graduated college & 140 & 40.0 & 95 & 40.43 & 45 & 39.13 \\
\hline Some post-graduate & 19 & 5.4 & 11 & 4.68 & 8 & 6.96 \\
\hline Completed post-graduate & 43 & 12.3 & 30 & 12.77 & 13 & 11.30 \\
\hline \multicolumn{7}{|l|}{ Marital status } \\
\hline Married & 320 & 91.7 & 213 & 90.64 & 107 & 93.86 \\
\hline Divorced & 12 & 3.4 & 9 & 3.83 & 3 & 2.63 \\
\hline Widowed & 1 & 0.3 & 1 & 0.43 & 0 & 0.00 \\
\hline Single & 10 & 3.4 & 10 & 4.26 & 0 & 0.00 \\
\hline Partners & 3 & 0.9 & 1 & 0.43 & 2 & 1.75 \\
\hline Other & 3 & 0.3 & 1 & 0.43 & 2 & 1.75 \\
\hline \multicolumn{7}{|l|}{ Race } \\
\hline White & 322 & 93.3 & 218 & 93.16 & 104 & 93.69 \\
\hline African American & 10 & 2.9 & 7 & 2.99 & 3 & 2.70 \\
\hline Asian & 6 & 1.7 & 5 & 2.14 & 1 & 0.90 \\
\hline Hispanic/Latino & 6 & 1.7 & 3 & 1.28 & 3 & 2.70 \\
\hline Multiracial & 1 & 0.3 & 1 & 0.43 & 0 & 0.00 \\
\hline \multicolumn{7}{|l|}{ Employment status } \\
\hline Employed full-time & 190 & 55.1 & 83 & 35.62 & 107 & 95.54 \\
\hline Employed part-time & 54 & 15.7 & 53 & 22.75 & 1 & 0.89 \\
\hline Student & 7 & 2.0 & 7 & 3.00 & 0 & 0.00 \\
\hline Retired & 4 & 1.2 & 2 & 0.86 & 2 & 1.79 \\
\hline Housewife/Househusband & 88 & 25.5 & 86 & 36.91 & 2 & 1.79 \\
\hline Other & 2 & 0.6 & 2 & 0.86 & 0 & 0.00 \\
\hline \multicolumn{7}{|l|}{ Household Income } \\
\hline$\$ 0$ to $\$ 5,000$ & 26 & 13.0 & 18 & 12.59 & 8 & 14.04 \\
\hline$\geq \$ 5,000$ and $<\$ 15,000$ & 11 & 5.5 & 6 & 4.20 & 5 & 8.77 \\
\hline$\geq \$ 15,000$ and $<\$ 20,000$ & 10 & 5.0 & 9 & 6.29 & 1 & 1.75 \\
\hline$\geq \$ 20,000$ and $<\$ 35,000$ & 20 & 10.0 & 17 & 11.89 & 3 & 5.26 \\
\hline$\geq \$ 35,000$ and $<\$ 50,000$ & 49 & 24.5 & 40 & 27.97 & 9 & 15.79 \\
\hline$\geq \$ 50,000$ & 84 & 42.0 & 53 & 37.06 & 31 & 54.39 \\
\hline
\end{tabular}




\section{Eligibility Screening}

Participant eligibility was assessed at the beginning of the interview by an item asking how many eligible children lived in the household. Households with at least one target child were eligible to participate. At this point in the interview, booster seats were described to the respondents, including notification that booster seats were not the same as infant and toddler child safety seats. Following this explanation, the respondents were asked how often the target children were placed in booster seats while riding in a car. Responses to this item were "never," "some of the time," "most of the time," and "always."

\section{Booster Seat Use}

Respondents were next asked how many booster seats were available for use by the target children living in the household. If the number of target children exceeded the number of available booster seats, respondents were asked which child did not ride in a booster seat (i.e., oldest, youngest, largest, or smallest). Part-time booster seat users (i.e., those responding that they used booster seats either some or most of the time) were next asked to indicate what percent of the time they placed their children in booster seats while driving.

\section{Conditions when Booster Seats are Used}

Part-time booster seat users were asked to indicate how often they used booster seats while driving in nine different circumstances, including local drives (less than 10 miles), short drives (10 to 60 miles), long drives (over 60 miles), drives in rural areas and suburban/urban areas, while driving on freeways and highways, and while during the nighttime and daytime. Responses were "never," "once in a while," "sometimes," and "usually/always."

\section{Reasons for Booster Seat Use}

Eight items asked part-time booster seat users to indicate their reasons for using booster seats, including: (yes or no) safety, reduce driver distraction, control child behavior, required by law, to allow the child to see out, increase child comfort, and because they had heard or read that booster seats should be used. Participants indicating that they used a booster seat because they heard they should, were asked if they had heard it (yes or no) at a child seat check point or health and safety fair, the hospital/doctor's office, the internet, from a friend, from a family member/relative, on TV or in other media, in a poster/brochure, or from a police officer. Respondents were then asked to indicate, of the eight options, which was their "primary reason" for using booster seats.

\section{Awareness of Booster Seat Safety and Regulations}

Several items assessed the part-time users' awareness of safety issues and regulations regarding booster seat use. They indicated who typically put the booster seat in the 
vehicle, how the person putting the seat in the vehicle had learned to install it, and where/how the booster seat had been acquired.

Next, part-time and non-users (i.e., those indicting that they never used a booster seat), were asked four questions measuring their awareness of booster seat safety issues and regulations. Respondents answered true or false to items making statements about the location in the car where child passengers are safest, legal requirements for booster seat use, effectiveness of booster seats in injury reduction, and enforcement of child restraint use laws. Following this set of four items, respondents indicating that booster seat use was required by Michigan State law were informed that booster seat use was not required by Michigan State law.

\section{Reasons for Booster Seat Use and Non-Use}

Part-time and non-booster seat users were asked to indicate their reasons for not using a booster seat. Eleven potential reasons were presented to the participants, who indicated which applied to them (yes or no). The potential reasons included: Being in a hurry; child refusal; too much hassle; ineffectiveness of booster seats; respondent and spouse disagreement on the safety benefits of booster seats; cost; child size; lack of legal requirements; unawareness of booster seats; not owning a booster seat; and that the child sometimes rode with other people who did not place them in a booster seat.

\section{Make Booster Seat Use Easier}

Factors that would make booster seats easier to use were identified by seven items asking part-time and non-users to indicate which (yes or no) would facilitate use. The factors included: seats built into the vehicle; the option to buy a seat when the car was purchased; children's preference to be in a booster seat; a law requiring booster seat use; free/reduced price programs; educational programs taken by parents and children together; and if everyone used them.

\section{Demographics}

Demographic information measured by the survey included educational attainment, number of rooms in the respondents' houses, family size, number of people living in the respondents' houses, marital status, age, sex, relationship to target child(ren), race, employment status, income, type of vehicle typically driven by the respondent, and sources of recent information on booster seats. These last items were included to measure the respondents' exposure to booster seat promotions sponsored at auto dealerships during the months preceding the interviews. 
RESULTS

Data analysis was conducted using contingency table analysis to compare pairs of categorical variables. These bivariate analyses were followed by multivariate models that were tested using logistic regression to identify sets of variables that predicted participant characteristics (i.e., part-time versus non-users). Dichotomous and multinomial logistic regression models were used as needed given the outcome being predicted. The models were tested using backwards elimination of predictors. The significance level for retaining variables in the model was .10.

All of the analyses were conducted on both the original data and on data weighted to correct for differences in racial distribution between the sample for this study and the Michigan population. The results of the weighted analyses were highly similar to those that used unweighted data, and led to the same conclusions; therefore, the results presented here are based on the observed data.

The results are organized into three groups including those: 1) for the entire sample; 2) specific to non-booster seat users; and, 3) specific to part-time booster seat users and non-users, together.

\section{Overview of Entire Sample}

The majority of the respondents reported either never (30 percent, 31 percent women, 28 percent men) or always ( 56 percent, 55 percent women, 57 percent men) using booster seats (Table 4); only 14 percent of the sample $(n=49)$ reported part-time booster seat use (see Table 4). When part-time users were asked what percent of the time they put their eligible children in booster seats while traveling, responses ranged from zero to 100 percent, with "50 percent of trips" being the most common response (eight respondents), followed by 95 percent (seven respondents), 75 percent (five respondents) and 98 percent (five respondents).

The number of booster seats available in the household ranged from none to four. Eight respondents reported having more target children than booster seats. When asked which child did not ride in a booster seat, six reported the oldest, one the largest, and one the smallest child.

Nearly 60 percent of the sample reported having only one target child, 36 percent reported two, and 4 percent reported having three or more target children. Vans (including full-size and minivans) were the most common vehicle used by the respondents (41 percent overall, 51 percent women, 21 percent of men).

Table 5 displays differences among the four booster seat use groups (i.e., never, some of the time, most of the time, and always), including counts, and row (R) and column (C) percents. Row percents can be used to compare across cells in the same row, while column percents are used to make comparisons across rows within a single cell of the table. A majority of Hispanic/Latino respondents said that they never used a booster seat, while a majority of White, African American, and Asian respondents 
reported always using booster seats. Most of the respondents who worked either partor full-time used booster seats some of the time, while most students and housewife/househusbands always used them, and retired respondents never used them. Generally, booster seat use increased with income, and was higher among drivers of SUVs than among other vehicles. Respondents who drove vans/minivans were more strongly represented in the "never" and "some of the time" use groups.

Table 4. Booster seat use, booster-aged, and vehicle type

\begin{tabular}{|c|c|c|c|c|c|c|}
\hline \multirow[b]{2}{*}{ Measure } & \multicolumn{2}{|c|}{$\begin{array}{l}\text { Overall } \\
(n=350)\end{array}$} & \multicolumn{2}{|c|}{$\begin{array}{l}\text { Women } \\
(n=235)\end{array}$} & \multicolumn{2}{|c|}{$\begin{array}{c}\text { Men } \\
(n=115)\end{array}$} \\
\hline & Count & Percent & Count & Percent & Count & Percent \\
\hline \multicolumn{7}{|l|}{ Booster seat use } \\
\hline Never & 105 & 30.0 & 73 & 31.1 & 32 & 27.8 \\
\hline Some of the time & 14 & 4.0 & 7 & 3.0 & 7 & 6.1 \\
\hline Most of the time & 35 & 10.0 & 25 & 10.6 & 10 & 8.7 \\
\hline Always & 196 & 56.0 & 130 & 55.3 & 66 & 57.4 \\
\hline \multicolumn{7}{|l|}{$\begin{array}{l}\text { Number target } \\
\text { children }\end{array}$} \\
\hline 1 & 207 & 59.1 & 145 & 61.7 & 62 & 53.9 \\
\hline 2 & 126 & 36.0 & 82 & 34.9 & 44 & 38.3 \\
\hline 3 & 15 & 4.3 & 8 & 3.4 & 7 & 6.1 \\
\hline 4 & 2 & 0.6 & & & 2 & 1.7 \\
\hline \multicolumn{7}{|l|}{ Vehicle Type } \\
\hline Passenger car & 87 & 24.9 & 56 & 23.8 & 31 & 27.2 \\
\hline Van/Minivan & 144 & 41.3 & 120 & 51.1 & 24 & 21.1 \\
\hline SUV & 91 & 26.1 & 54 & 23.0 & 37 & 32.5 \\
\hline Pickup truck & 27 & 7.7 & 5 & 2.1 & 22 & 19.3 \\
\hline
\end{tabular}

\section{Part-Time Booster Seat Users}

\section{Booster Seat Use by Driving Condition}

The sample of part-time booster seat users was quite small $(n=49)$, and resulted in small cells. As a result, it is possible that there may be insufficient power to detect true effects. Therefore, throughout this section, relative risk ratios are examined in addition to significance tests to interpret the results.

Part-time booster seat users were asked how often they placed their children in booster seats when they were driving on different roadways and times of day, including local drives (i.e., less than 10 miles), short drives (i.e., 10 to 60 miles), long drives (i.e., over 60 miles), rural, urban/suburban, freeway, highway, nighttime and daytime driving. Overall use by sex is illustrated graphically in Figure 1. 
Table 5. Description of participants by their self-reported booster seat use

\begin{tabular}{|c|c|c|c|c|c|c|c|c|c|c|c|c|}
\hline \multirow{4}{*}{$\begin{array}{l}\text { Measure } \\
\text { Number target children } \\
1\end{array}$} & \multicolumn{3}{|c|}{ Never } & \multicolumn{3}{|c|}{ Some of the Time } & \multicolumn{3}{|c|}{ Most of the Time } & \multicolumn{3}{|c|}{ Always } \\
\hline & \multirow{2}{*}{ Count } & \multicolumn{2}{|c|}{ Percent } & \multirow[t]{2}{*}{ Count } & \multicolumn{2}{|c|}{ Percent } & \multirow[t]{2}{*}{ Count } & \multicolumn{2}{|c|}{ Percent } & \multirow{2}{*}{ Count } & \multicolumn{2}{|c|}{ Percent } \\
\hline & & $\mathrm{C}^{1}$ & $\mathrm{R}^{2}$ & & $\mathrm{C}^{1}$ & $\mathrm{R}^{2}$ & & $\mathrm{C}^{1}$ & $\mathrm{R}^{2}$ & & $\mathrm{C}^{1}$ & $\mathrm{R}^{2}$ \\
\hline & 70 & 67 & 34 & 6 & 43 & 3 & 22 & 63 & 11 & 109 & 56 & 53 \\
\hline 2 & 31 & 30 & 25 & 7 & 50 & 6 & 11 & 31 & 9 & 77 & 39 & 61 \\
\hline 3 & 4 & 4 & 27 & 0 & 0 & 0 & 1 & 3 & 7 & 10 & 5 & 67 \\
\hline 4 & 0 & 0 & 0 & 1 & 7 & 50 & 1 & 3 & 50 & 0 & 0 & 0 \\
\hline $\begin{array}{l}\text { Who responded } \\
\text { Mother }\end{array}$ & 69 & 66 & 30 & 7 & 50 & 3 & 25 & 71 & 11 & 128 & 65 & 56 \\
\hline Father & 32 & 30 & 28 & 7 & 50 & 6 & 10 & 29 & 9 & 65 & 33 & 57 \\
\hline Step-mother & 1 & 1 & 100 & 0 & 0 & 0 & 0 & 0 & 0 & 0 & 0 & 0 \\
\hline Step-father & 0 & 0 & 0 & 0 & 0 & 0 & 0 & 0 & 0 & 1 & 1 & 100 \\
\hline Other adult relative & 3 & 3 & 60 & 0 & 0 & 0 & 0 & 0 & 0 & 2 & 1 & 40 \\
\hline $\begin{array}{l}\text { Completed education } \\
\text { Less than high school }\end{array}$ & 4 & 4 & 67 & 0 & 0 & 0 & 0 & 0 & 0 & 2 & 1 & 33 \\
\hline High school & 23 & 22 & 38 & 4 & 29 & 7 & 4 & 11 & 7 & 29 & 15 & 48 \\
\hline Some college/ trade school & 23 & 22 & 28 & 3 & 21 & 4 & 10 & 29 & 12 & 46 & 23 & 56 \\
\hline Graduated college & 36 & 34 & 26 & 7 & 50 & 5 & 13 & 37 & 9 & 84 & 43 & 60 \\
\hline Some post-graduate & 8 & 8 & 42 & 0 & 0 & 0 & 2 & 6 & 11 & 9 & 5 & 47 \\
\hline Completed post-graduate & 11 & 10 & 26 & 0 & 0 & 0 & 6 & 17 & 14 & 26 & 13 & 61 \\
\hline Marital status & & & & & & & & & & & & \\
\hline Married & 93 & 89 & 29 & 13 & 93 & 4 & 33 & 94 & 10 & 181 & 93 & 57 \\
\hline Divorced & 4 & 4 & 33 & 1 & 7 & 8 & 0 & 0 & 0 & 7 & 4 & 58 \\
\hline Widowed & 0 & 0 & 0 & 0 & 0 & 0 & 0 & 0 & 0 & 1 & 1 & 100 \\
\hline Single & 5 & 5 & 42 & 0 & 0 & 0 & 1 & 3 & 8 & 6 & 3 & 50 \\
\hline Partners & 3 & 3 & 100 & 0 & 0 & 0 & 0 & 0 & 0 & 0 & 0 & 0 \\
\hline Other & 0 & 0 & 0 & 0 & 0 & 0 & 1 & 3 & 100 & 0 & 0 & 0 \\
\hline
\end{tabular}




\begin{tabular}{|c|c|c|c|c|c|c|c|c|c|c|c|c|}
\hline \multirow{4}{*}{$\begin{array}{l}\text { Measure } \\
\text { Number target children } \\
\text { Race }\end{array}$} & \multicolumn{3}{|c|}{ Never } & \multicolumn{3}{|c|}{ Some of the Time } & \multicolumn{3}{|c|}{ Most of the Time } & \multicolumn{3}{|c|}{ Always } \\
\hline & \multirow[t]{3}{*}{ Count } & \multicolumn{2}{|c|}{ Percent } & \multirow[t]{3}{*}{ Count } & \multicolumn{2}{|c|}{ Percent } & \multirow[t]{3}{*}{ Count } & \multicolumn{2}{|c|}{ Percent } & \multirow[t]{3}{*}{ Count } & \multicolumn{2}{|c|}{ Percent } \\
\hline & & $\mathrm{C}^{1}$ & $\mathrm{R}^{2}$ & & $\mathrm{C}^{1}$ & $\mathrm{R}^{2}$ & & $\mathrm{C}^{1}$ & $\mathrm{R}^{2}$ & & $\mathrm{C}^{1}$ & $\mathrm{R}^{2}$ \\
\hline & & & & & & & & & & & & \\
\hline White & 95 & 91 & 30 & 14 & 100 & 4 & 32 & 91 & 10 & 181 & 94 & 56 \\
\hline African American & 4 & 4 & 40 & 0 & 0 & 0 & 1 & 3 & 10 & 5 & 3 & 50 \\
\hline Asian & 1 & 1 & 17 & 0 & 0 & 0 & 1 & 3 & 17 & 4 & 2 & 67 \\
\hline Hispanic/Latino & 3 & 3 & 50 & 0 & 0 & 0 & 1 & 3 & 17 & 2 & 1 & 33 \\
\hline Multiracial & 1 & 1 & 100 & 0 & 0 & 0 & 0 & 0 & 0 & 0 & 0 & 0 \\
\hline Employment status & & & & & & & & & & & & \\
\hline Employed full-time & 59 & 57 & 31 & 9 & 69 & 5 & 21 & 60 & 11 & 101 & 52 & 53 \\
\hline Employed part-time & 16 & 15 & 30 & 4 & 31 & 7 & 3 & 9 & 6 & 31 & 16 & 57 \\
\hline Student & 1 & 1 & 14 & 0 & 0 & 0 & 1 & 3 & 14 & 5 & 3 & 71 \\
\hline Retired & 4 & 4 & 100 & 0 & 0 & 0 & 0 & 0 & 0 & 0 & 0 & 0 \\
\hline Housewife/Househusband & 23 & 22 & 26 & 0 & 0 & 0 & 10 & 29 & 11 & 55 & 29 & 63 \\
\hline Other & 1 & 1 & 50 & 0 & 0 & 0 & 0 & 0 & 0 & 1 & 1 & 50 \\
\hline Household income & & & & & & & & & & & & \\
\hline$\$ 0$ to $\$ 5,000$ & 4 & 6 & 15 & 0 & 0 & 0 & 1 & 7 & 4 & 21 & 19 & 81 \\
\hline$>\$ 5,000$ and $<\$ 15,000$ & 4 & 6 & 36 & 3 & 25 & 27 & 2 & 14 & 18 & 2 & 2 & 18 \\
\hline$>\$ 15,000$ and $<\$ 20,000$ & 3 & 5 & 30 & 0 & 0 & 0 & 2 & 14 & 20 & 5 & 5 & 50 \\
\hline$>\$ 20,000$ and $<\$ 35,000$ & 8 & 13 & 40 & 0 & 0 & 0 & 1 & 7 & 5 & 11 & 10 & 55 \\
\hline$>\$ 35,000$ and $<\$ 50,000$ & 17 & 27 & 35 & 3 & 25 & 6 & 2 & 14 & 4 & 27 & 24 & 55 \\
\hline$>\$ 50,000$ to $\$ 75,000$ & 27 & 43 & 32 & 6 & 50 & 7 & 6 & 43 & 7 & 45 & 41 & 54 \\
\hline Vehicle type & & & & & & & & & & & & \\
\hline Passenger car & 25 & 24 & 29 & 3 & 21 & 4 & 9 & 26 & 10 & 50 & 26 & 58 \\
\hline Van/Minivan & 43 & 41 & 30 & 8 & 57 & 6 & 12 & 35 & 8 & 81 & 41 & 56 \\
\hline SUV & 28 & 27 & 31 & 2 & 14 & 2 & 9 & 26 & 10 & 52 & 27 & 57 \\
\hline Pickup truck & 9 & 9 & 33 & 1 & 7 & 4 & 4 & 12 & 15 & 13 & 7 & 48 \\
\hline
\end{tabular}

1- Column percent

2- Row percent 


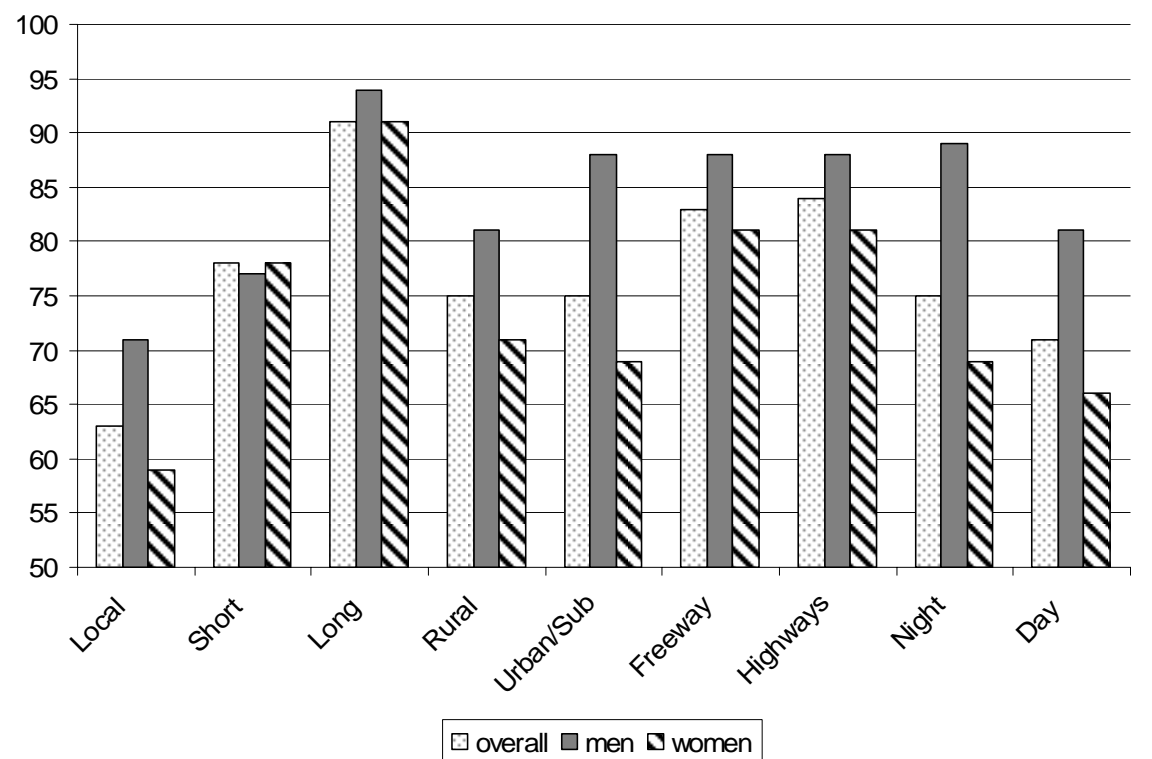

\section{Figure 1. Percent booster seat use overall, and for men and women in various driving situations}

Overall, over 70 percent of parents reported that they used a booster seat in all types of driving measured, with the exception of short trips. Only 63 percent of parents reported that they always used a booster seat when driving a short distance. Of all types of trips measured, men and women were least likely to use a booster seat when taking a short trip. When compared statistically, using cross-tabulations and chisquare tests, no significant differences between men and women emerged (see Table 6); however, relative risk ratios deviated substantially from 1.00 for all driving circumstances, except short drives. Risk ratios substantially less than 1.00 indicate that female part-time users were generally less likely than male part-time users to report always placing their children in booster seats when driving under each of the conditions. The likelihood that women's use would be less than always in the observed conditions ranged from 3.2 times less likely than men when driving at night and on urban/suburban roadways, to 1.6 times less likely when taking local drives.

\section{Motivations to Use Booster Seats}

Part-time booster seat users were also asked to indicate whether they were motivated (yes or no) to use booster seats by each of eight common reasons. All part-time users indicated that child safety was one reason they used booster seats. Differences were seen between men and women on the remaining seven reasons, and are illustrated in Figure 2.

The only significant effect of sex was for women (see Table 7), who were 5.6 times $(\mathrm{p}=.008)$ more likely than men to use a booster seat so that the shoulder belt did not rub across the child's neck. Similarly, women had a higher likelihood of using booster seats for other reasons related to child comfort, including so the child can see 
out (relative risk $=3.04$ ) and so the child is comfortable (risk ratio $=1.14$ ); however the risk ratio for the latter reason was too small to be considered meaningful.

Table 6. Driving circumstances when booster seats are always used - a comparison of men and women

\begin{tabular}{l|r|c|c|c|c|}
\hline & & & \multirow{2}{*}{$\begin{array}{c}\text { Relative } \\
\text { Variables }\end{array}$} & \multicolumn{2}{|c|}{ 95\% CL } \\
\cline { 5 - 7 } & $\mathbf{X}^{\mathbf{2}}$ & $\mathbf{p}$ & Risk & Lower & Upper \\
\hline Local drives & .60 & .438 & .61 & .17 & 2.15 \\
Short drives & .02 & .895 & 1.10 & .27 & 4.45 \\
Long drives & .18 & .671 & .60 & .06 & 6.30 \\
Rural drives & .59 & .444 & .56 & .13 & 2.47 \\
Suburban/urban drives & 2.00 & .157 & .31 & .06 & 1.65 \\
Freeway drives & .30 & .584 & .62 & .11 & 3.48 \\
Highway drives & .40 & .529 & .58 & .10 & 3.23 \\
Nighttime drives & 2.00 & .157 & .31 & .06 & 1.65 \\
Daytime drives & 1.26 & .262 & .44 & .10 & 1.88 \\
\hline
\end{tabular}

Women were about three times more likely than men to say that they used a booster seat because it is the law in Michigan; however, the impression that booster seat use was mandated by Michigan law was mistaken, as there was no booster seat law at the time of the survey.

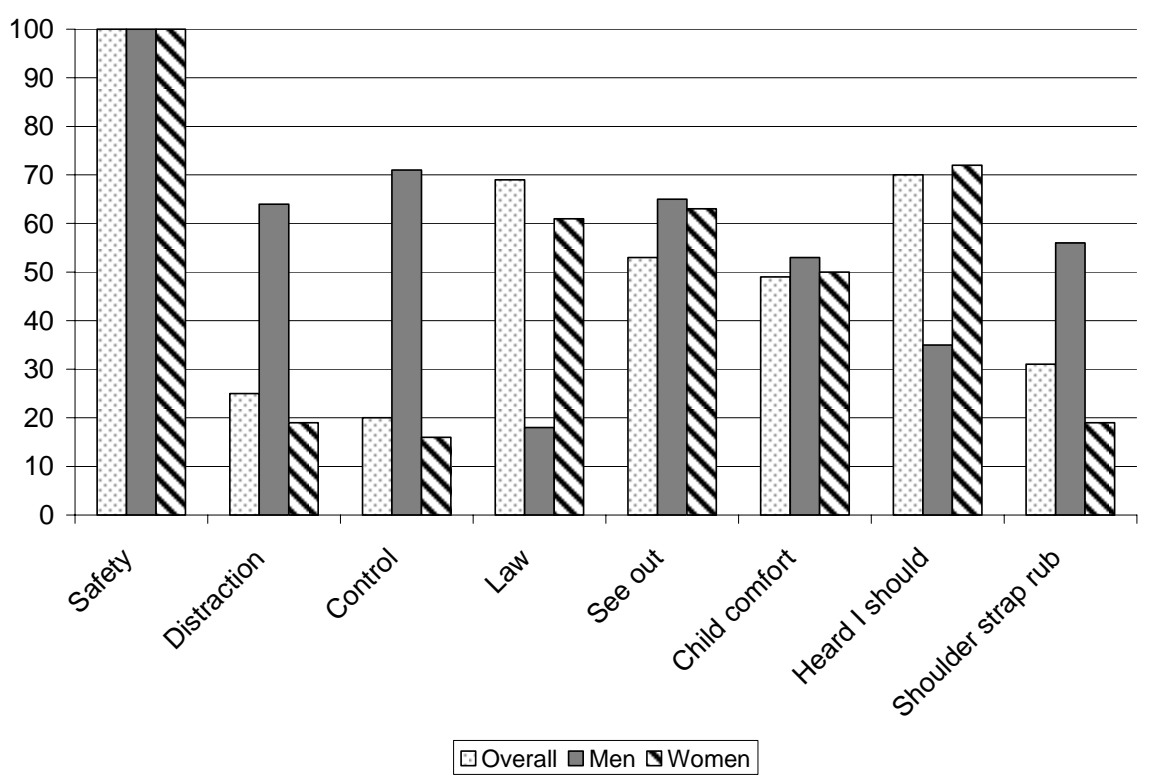

Figure 2. Motivations for using booster seats by sex 
Overall, parents were unlikely to list control of the child's behavior as a motivation to use a booster seat; however, this is more due to mothers than fathers. Men were more likely than women to use booster seats as a means of limiting the child's activity in the vehicle, being 2.4 (risk ratio $=.42$ ) times more likely than women to use booster seats to limit distraction due to the child's activity, and 2.3 times more likely to use the booster seats to control the child's behavior.

Table 7. Reasons for using a booster seat

\begin{tabular}{|c|c|c|c|c|c|}
\hline \multirow[b]{2}{*}{ Variables } & \multirow[b]{2}{*}{$X^{2}$} & \multirow[b]{2}{*}{$\mathbf{p}$} & \multirow{2}{*}{$\begin{array}{c}\text { Relative } \\
\text { risk }\end{array}$} & \multicolumn{2}{|c|}{ 95\% CL } \\
\hline & & & & Lower & Upper \\
\hline Avoid distraction & 1.64 & .199 & .42 & .62 & 8.97 \\
\hline Control child's behavior & 1.30 & .254 & .44 & .55 & 9.25 \\
\hline It's the law & 2.27 & .132 & 2.94 & .70 & 12.46 \\
\hline So child can see out & 3.30 & .069 & 3.04 & .10 & 1.11 \\
\hline So child is comfortable & .05 & .831 & 1.14 & .26 & 3.99 \\
\hline Heard I should & .27 & .604 & 1.39 & .20 & 2.52 \\
\hline So belt won't rub child's neck & 6.98 & .008 & .18 & .05 & .68 \\
\hline
\end{tabular}

Part-time booster seat users $(n=49)$ were asked where they had heard about booster seats. The most common response $(n=46)$ was a booster seat checking station $(90$ percent) followed by friends ( 2 percent) and family ( 2 percent). When asked who typically placed the booster seat in the vehicle, 38 said they usually put the booster seat in the vehicle (79 percent; 21 percent men, 58 percent women), followed by another family member ( 13 percent; 6 percent men, 6 percent women), and a friend ( 8 percent; 6 percent men, 2 percent women). When asked where they had acquired the booster seat, 45 part-time users had purchased it themselves ( 79 percent; 21 percent men, 58 percent women), three had received it from a family member ( 6 percent; 6 percent men, 0 percent women), and one indicated that it came built into the car (2 percent; 0 percent men, 2 percent women).

\section{Part-Time and Non-Booster Seat Users}

\section{Knowledge and Opinions}

Survey participants were asked to answer true or false to four statements about child passenger safety. Sex differences are illustrated in Figure 3. Men and women were similar in their responses to all four questions. Ninety-eight percent knew that children were safest when riding in the back seat of a vehicle. Approximately 35 percent of men and women thought that booster seats were required by law; over 90 percent knew that booster seats reduced injury, and about 20 percent believed that the police do not enforce child restraint use laws (see Table 8). 
There was a significant difference by sex in the belief that the back seat is the safest location for children; however, the relative risk was very small (see Table 8).

Similarly, men were 4.7 times less likely than women to believe that booster seats reduced injury, but overall correct opinions on this item exceeded 90 percent. Due to the large proportion of individuals expressing accurate perceptions on these two items, there are very few individuals with inaccurate opinions on which to base the statistical tests and calculation of risk ratios. In these two cases, the significant test for the first item and the very small relative risk for the second are most likely a result of small cell sizes, and should not be over-interpreted. Of interest, however, is that women were 1.9 times more likely than men to believe that police officers do not enforce child safety seat laws.

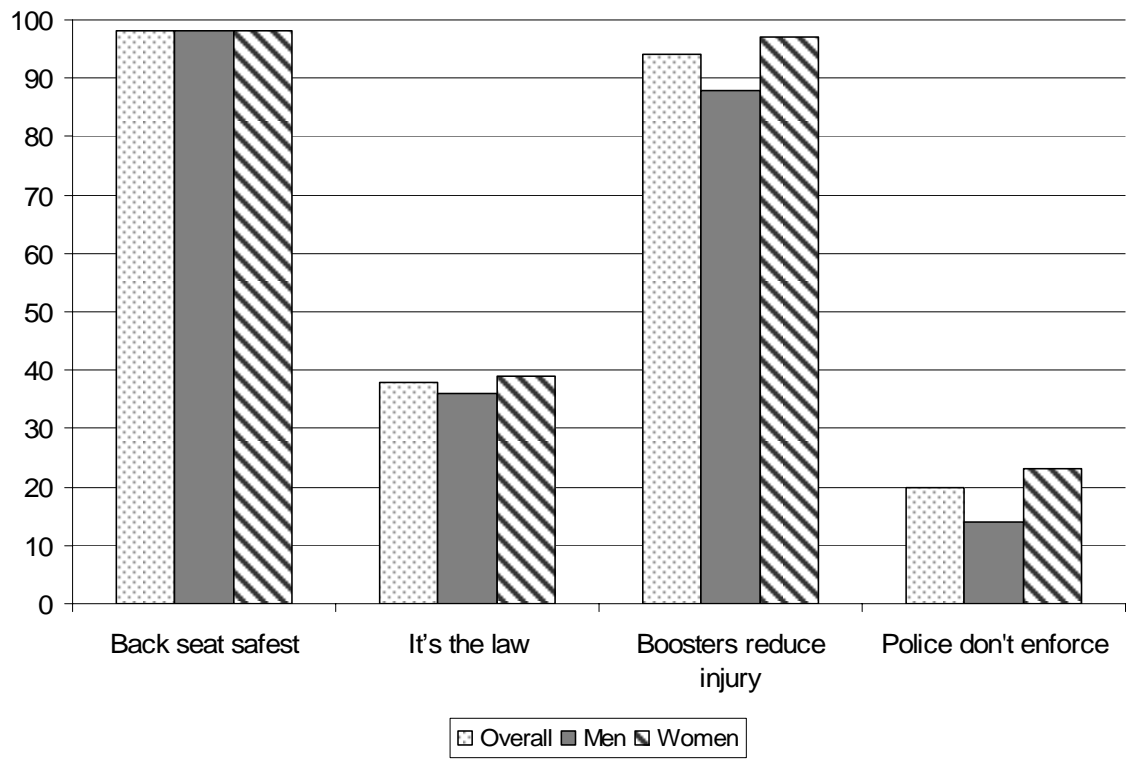

Figure 3. Percent responding “True” by sex

When responses to the same four items were compared between part-time and never booster seat users, a few differences emerged (see Figure 4). Part-time users were more likely than non-users to believe that booster seat use was mandated by law and less likely to believe that police officers do not enforce child safety seat laws.

Table 8. Opinions regarding child safety and booster seats by sex

\begin{tabular}{l|c|c|c|r|r|}
\hline & & & \multirow{2}{*}{$\begin{array}{c}\text { Relative } \\
\text { Variables }\end{array}$} & & \multicolumn{2}{|c|}{ 95\% CL } \\
\cline { 5 - 7 } & $\mathbf{X}^{\mathbf{2}}$ & $\mathbf{p}$ & risk & Lower & Upper \\
\hline Back seat safest & .00 & .971 & .95 & .08 & 10.74 \\
Booster seats required by law & .05 & .814 & .91 & .43 & 1.93 \\
Booster seats reduce injury & 5.29 & .022 & .21 & .05 & .89 \\
Police do not enforce child safety seat laws & 1.69 & .193 & .52 & .20 & 1.40 \\
\hline
\end{tabular}


Similar to the results of the sex comparisons of these items, over 90 percent of the respondents agreed that the back seat of the car is the safest place for children, and booster seats are effective in reducing injury. Additionally, people reported accurate understandings of booster seat law in Michigan, and correct perceptions of enforcement activity as it relates to child safety restraints. As a consequence, cell sizes are especially small, and the results of the statistical analyses should not be over-interpreted for these items. Part-time users were 3.0 times more likely than nonusers to believe that booster seat use was required by law, and this effect was statistically significant (see Table 9). Additionally, non-users were 1.9 times more likely than part-time users to believe that police officers do not enforce child safety seat laws.

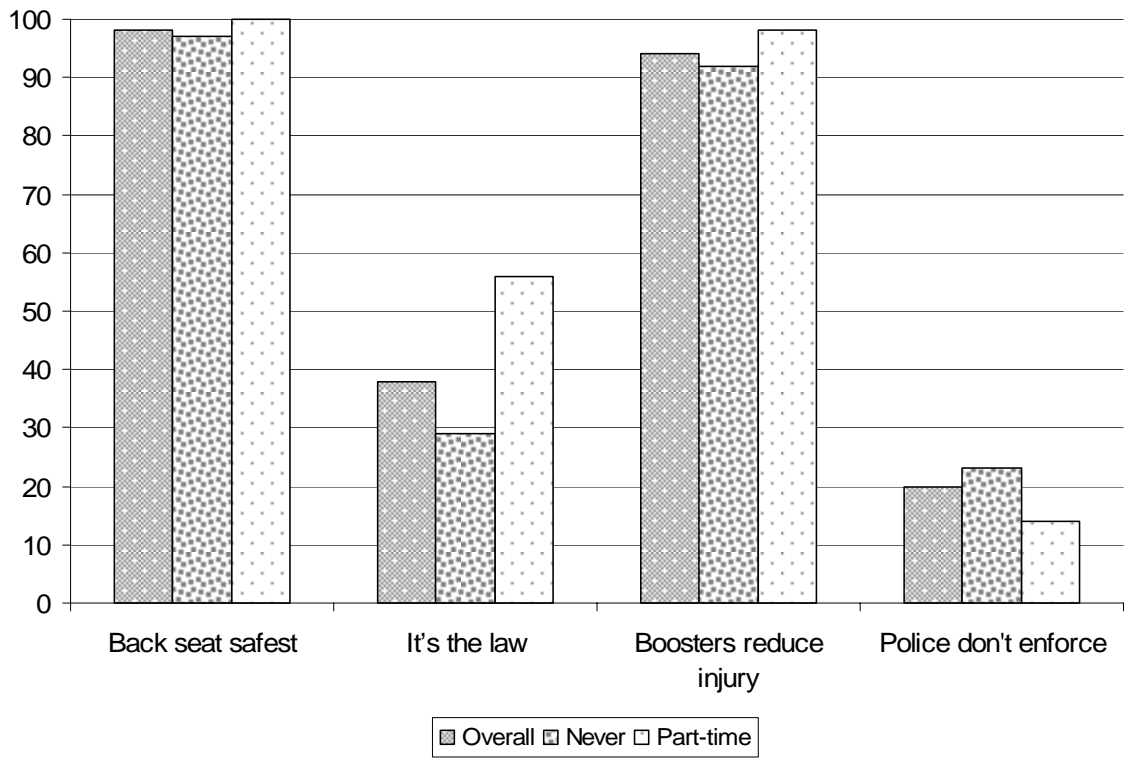

Figure 4. Percent responding “True” by never versus part-time use

After being asked the previous questions, the respondents who said that booster seat use was mandated by state law were given correct information by the interviewer, who told the respondent that there was currently no law in Michigan that required booster seat use. Then, all part-time and non-users were asked if they would be more likely to use a booster seat if there were a law that required it. Twenty-four percent of

Table 9. Opinions regarding child safety and booster seats by booster seat use

\begin{tabular}{l|c|c|c|c|c|}
\hline & & & \multirow{2}{*}{ Relative } & \multicolumn{2}{|c|}{ 95\% CL } \\
\cline { 6 - 7 } Variables & $\mathbf{X}^{2}$ & $\mathbf{p}$ & risk & Lower & Upper \\
\hline Back seat safest & 1.46 & .228 & .67 & .60 & .75 \\
Booster seats required by law & 8.73 & .003 & .33 & .16 & .70 \\
Booster seats reduce injury & 2.02 & .155 & .24 & .03 & 1.99 \\
Police do not enforce child safety seat laws & 1.69 & .193 & 1.91 & .71 & 5.11 \\
\hline
\end{tabular}


men and 56 percent of women said yes. Results of statistical analysis showed a nonsignificant effect $\left(\chi^{2}=0.86, p=.353\right)$, but the relative risk ratio indicated that women were 1.5 times more likely than men to say that a law would increase their likelihood of use (relative risk ratio $=0.68,95$ percent confidence interval $[\mathrm{CI}] 0.30$ to 1.54 ). When comparisons were made by use group, 11.3 percent of part-time users and 9.3 percent of non-users said no. Statistical analyses showed that non-users were 3.5 times more likely than part-time users to indicate that a law would increase their booster seat use $\left(\chi^{2}=9.56, \mathrm{p}=<.002\right.$; relative risk ratio $=3.49,95$ percent CI 1.54 to 7.89).

\section{Reasons for Not Using Booster Seats}

Part-time and non-users were queried about their reasons for not using a booster seat. Eleven common reasons for not using booster seats were stated individually, and respondents replied either yes (This is a reason I do not use a booster seat) or no (This is not a reason why I do not use a booster seat). Responses to the eleven items were compared by sex (see Figure 5).

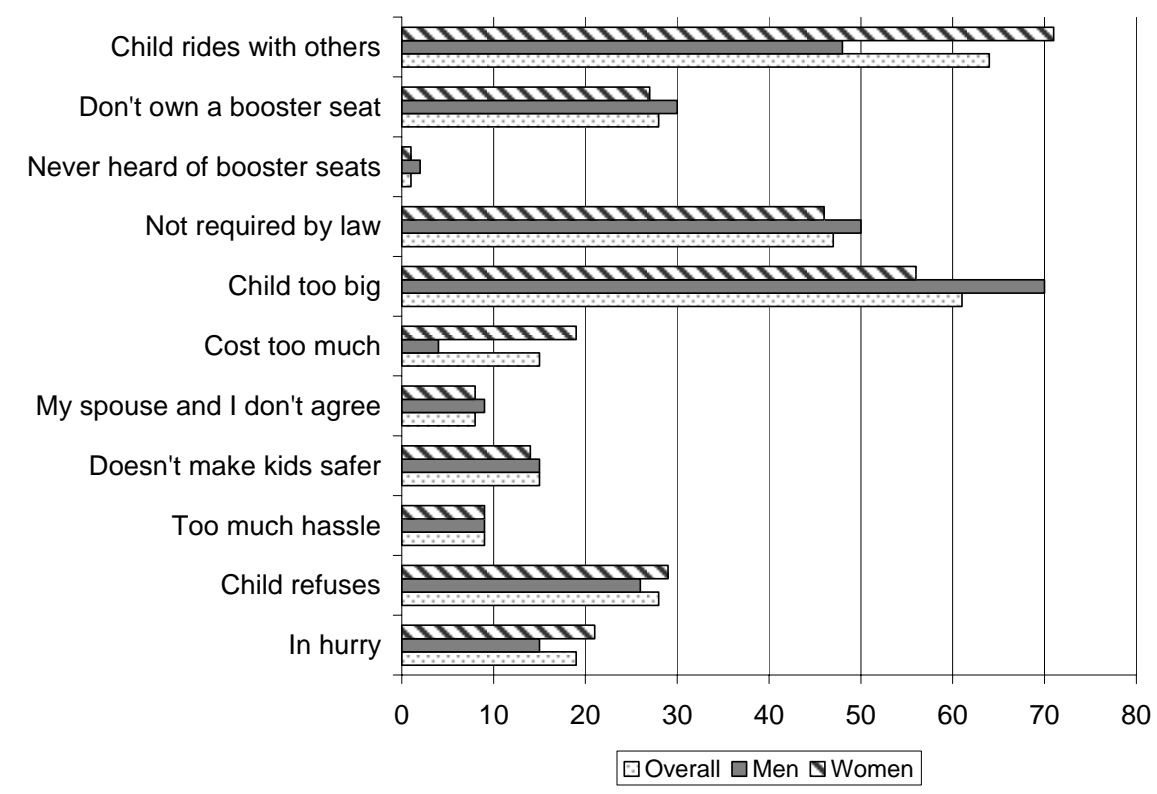

Figure 5. Percent endorsement of reasons for booster seat non-use by sex

Generally, the statistical tests were not significant, but the relative risks associated with several of the items were notable (see Table 10). Women were 2.7 times more likely than men to feel that letting the child ride in other people's cars made it more difficult to use booster seats. Although the relative risk for having never heard of booster seats was greater than two, it was based on very small cells, and should be interpreted conservatively. Men were 1.8 times more likely to say that they did not use booster seats because their child was too big, and women were five times more likely to say that purchase cost influenced their decision to use a booster seat, and 1.5 times more likely to say that they did not use booster seats when they were in a hurry. 
The relative risk for all other comparisons was close to 1.0, and should be interpreted cautiously.

Table 10. Reasons for booster seat non-use by sex

\begin{tabular}{lr|c|c|c|c|}
\hline & & & \multirow{2}{*}{ Relative } & \multicolumn{2}{|c|}{ 95\% CL } \\
\cline { 5 - 6 } Variables & $\mathbf{X}^{2}$ & $\mathbf{p}$ & risk & Lower & Upper \\
\hline Child rides with others & 7.76 & .005 & .37 & .18 & .75 \\
Don't own a booster seat & .16 & .691 & 1.17 & .55 & 2.49 \\
Never heard of booster seats & .37 & .546 & 2.31 & .14 & 37.80 \\
Not required by law & .21 & .647 & 1.18 & .58 & 2.41 \\
Child too big & 2.67 & .102 & 1.84 & .88 & 3.83 \\
Cost too much & 5.46 & .020 & .20 & .04 & .87 \\
My spouse and I don't agree & .06 & .805 & 1.17 & .33 & 4.11 \\
Doesn't make children safer & .02 & .900 & 1.07 & .40 & 2.82 \\
Too much hassle & $<.00$ & .993 & 1.01 & .29 & 3.45 \\
Child refuses & .12 & .729 & .87 & .40 & 1.90 \\
In a hurry & .82 & .366 & .65 & .26 & 1.65 \\
\hline
\end{tabular}

\section{Reasons for Using Booster Seats}

Part-time and non-users were compared on their reasons for not using booster seats. These two groups differed on several items (see Figure 6).

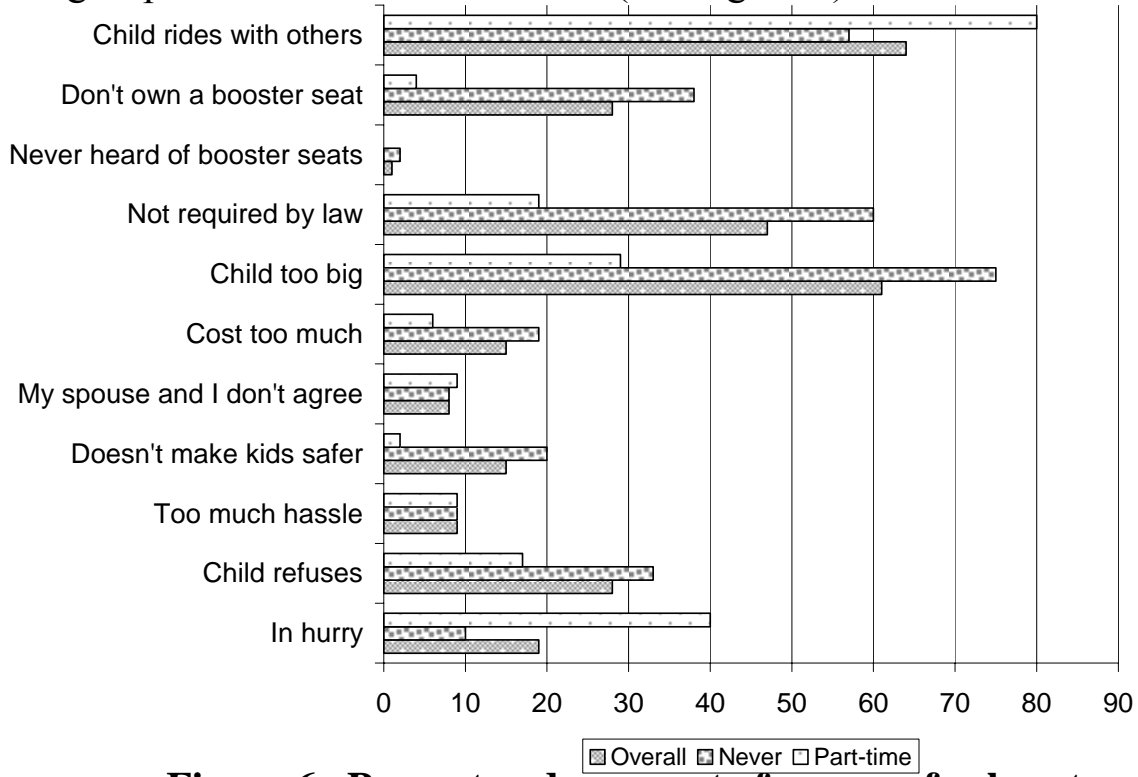

Figure 6. Percent endorsement of reasons for booster seat non-use by part-time versus never use

Table 11 quantifies the differences illustrated in Figure 6. Compared to non-users, part-time booster seat users were 3.1 time more likely to say that having the child ride 
with others, and 6.3 times more likely to say that being in a hurry made it more difficult to use a booster seat. Non-users were 1.5 times more likely than part-time users to say they had never heard of booster seats. They were 6.5 times more likely to say that they did not use a booster seat because it was not required by law, 7.3 times more likely because their child was too big, 3.4 times more likely because booster seats cost too much, and 2.4 times more likely because the child refuses. Although it is based on few responses by part-time users, non-users were 11.4 times more likely to indicate that they did not use a booster seat because they did not believe that booster seats made children safer. A large relative risk was associated with having never heard of booster seats, but was based on very small cells in both groups and should not be over-interpreted.

Table 11. Reasons for booster seat non-use by use group

\begin{tabular}{|l|r|r|r|r|r|}
\hline & & & Relative & \multicolumn{2}{|c|}{ 95\% CL } \\
\cline { 5 - 6 } Variables & \multicolumn{1}{|c|}{$\mathbf{X}^{\mathbf{2}}$} & $\mathbf{p}$ & risk & Lower & Upper \\
\hline Child rides with others & 7.55 & .006 & .32 & .14 & .74 \\
\hline Don't own a booster seat & 18.59 & $<.001$ & 13.85 & 3.18 & 60.23 \\
\hline Never heard of booster seats & .89 & .346 & 1.45 & 1.30 & 1.61 \\
\hline Not required by law & 20.28 & $<.001$ & 6.51 & 2.73 & 15.51 \\
\hline Child too big & 28.88 & $<.001$ & 7.29 & 3.39 & 15.65 \\
\hline Cost too much & 3.83 & .050 & 3.36 & .94 & 11.97 \\
\hline My spouse and I don't agree & .02 & .889 & .91 & .26 & 3.20 \\
\hline Doesn't make children safer & 8.27 & .004 & 11.39 & 1.48 & 87.44 \\
\hline Too much hassle & $<.00$ & .963 & 1.03 & .30 & 3.53 \\
\hline Child refuses & 4.09 & .043 & 2.40 & 1.01 & 5.70 \\
\hline In a hurry & 18.83 & $<.001$ & .16 & .07 & .39 \\
\hline
\end{tabular}

\section{Making Booster Seat Use Easier}

In an effort to identify potential interventions that would increase booster seat use, part-time and non-booster seat users were asked to indicate what would make it easier for them to use a booster seat. Comparisons of men and women are illustrated in Figure 7.

Compared to men, women were 2.4 times more likely to say that it would be easier to use a booster seat if it were built into the car, 2.2 times more likely if it was required by law, 1.7 times more likely if there were educational programs, and 4.5 times more likely if everyone used them.

Comparisons on the same items were made between part-time and non-users. Most of the differences were small (see Figure 8). Compared to non-users, part-time users were 1.4 times more likely to say that having the option to buy the booster seat with the car would make it easier to use a booster seat, and 1.4 times more likely to say that free/reduced booster seat programs would make it easier (see Table 13). Nonusers were 1.4 times more likely to say that it would be easier to use a booster seat if 
the child liked it, and 2.7 times more likely to say that it would be easier for them if it were required by law.

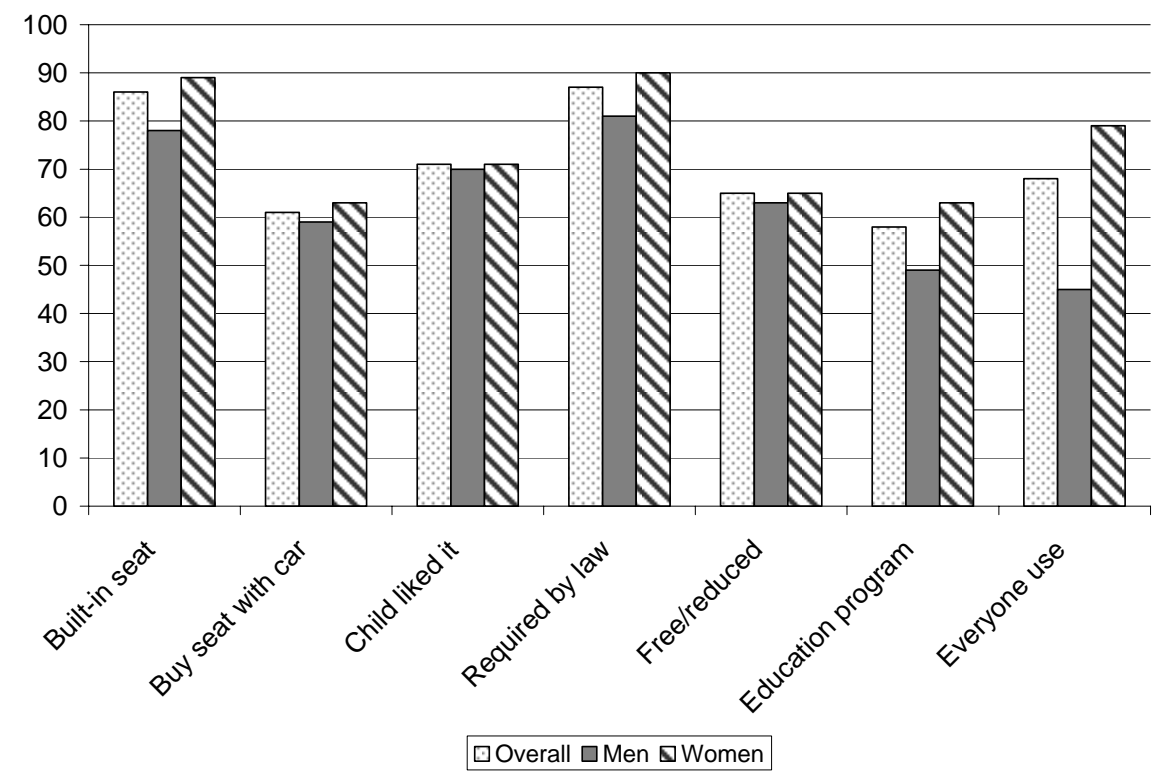

Figure 7. What would make booster seat use easier by sex

\section{Multivariate Model Testing}

Multivariate logistic regression models were tested to identify sets of items that differentiated between never, part-time, and always users, men and women, and part-time and non-users. The purpose of these models was to identify multivariate combinations of the variables examined on a bivariate basis in the previous section.

Table 12. What would make booster seat use easier by sex

\begin{tabular}{l|r|c|c|cc|}
\hline & & & Relative & \multicolumn{2}{|c|}{ 95\% CL } \\
\cline { 5 - 6 } Variables & $\mathbf{X}^{\mathbf{2}}$ & $\mathbf{p}$ & Risk & Lower & Upper \\
\hline Seat built in & 3.71 & .054 & .41 & .17 & 1.03 \\
Buy with car & .15 & .694 & .87 & .43 & 1.74 \\
Child liked it & .04 & .842 & .92 & .42 & 2.02 \\
Required by law & 2.60 & .107 & .45 & .17 & 1.21 \\
Free/reduced & .12 & .730 & .88 & .43 & 1.80 \\
Educational program & 2.50 & .114 & .58 & .29 & 1.14 \\
Everyone used & 17.01 & $<.001$ & .22 & .11 & .46 \\
\hline
\end{tabular}

\section{Never, Part-time and Always Use}

All of the survey participants were included in these analyses. Predictors were demographic characteristics. Some were recoded for the purposes of these analyses and their recoded values are given in parentheses. Predictors including number of children (i.e., 1 and 2 or more), educational level, marital status (i.e., collapsed into 
married versus not married), full-time employment (i.e., employed versus not employed), income level, and age. Because the outcome variable was trichotomous, models were constructed using multinomial logistic regression.

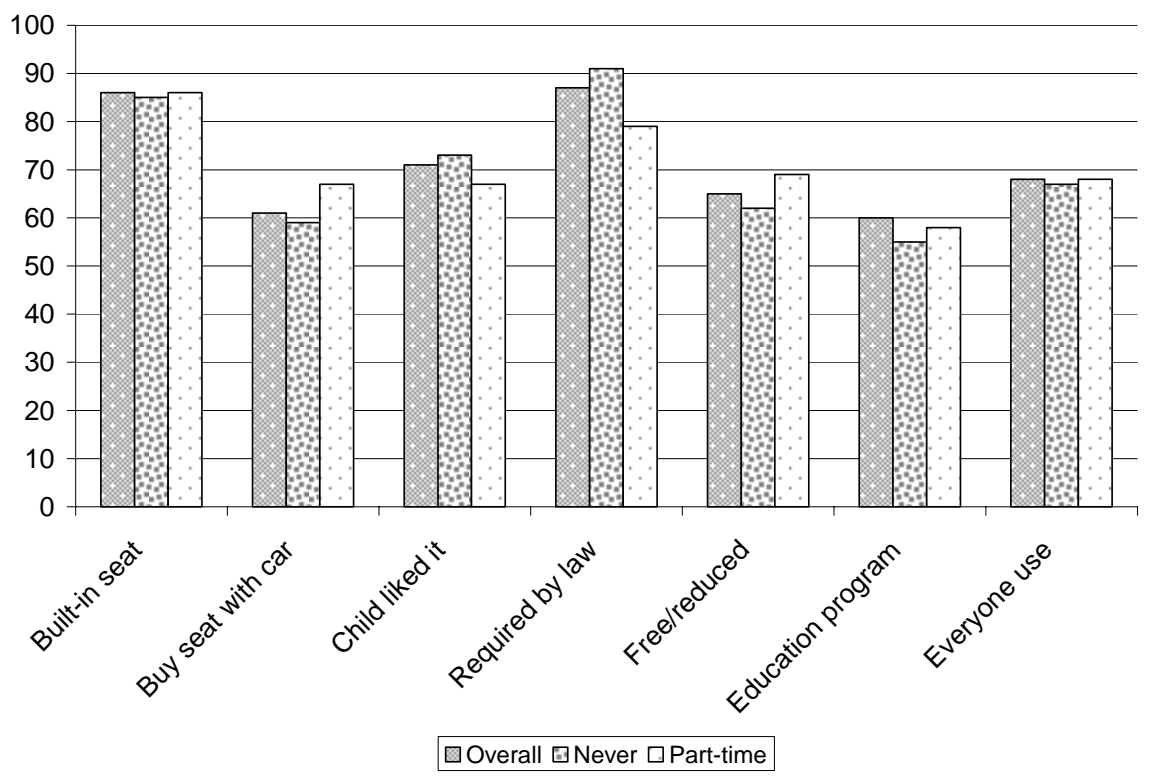

Figure 8. What would make booster seat use easier by use group

The only significant predictor was number of children (see Table 13). The overall model was significant (Wald $\chi^{2}(2)=6.47, p=.039$ ). Results indicated that respondents with more than one booster-seat-aged child were 2.4 times more likely $(2.39,95$ percent $\mathrm{CI}=1.21$ to 4.72$)$ to always use a booster seat than were participants with one child. When the model was adjusted for SES, the effect of the number of children on the likelihood of never using booster seats was reduced from 2.4 to 2.2 , but remained significant (Wald $\chi^{2}(1)=4.86, p=.028$ ), suggesting that SES accounted for some, but not all of the effect of number of target children on booster seat use.

Table 13. What would make booster seat use easier by use group

\begin{tabular}{lrr|r|rc|}
\hline & & & Relative & \multicolumn{2}{|c|}{ 95\% CL } \\
\cline { 5 - 6 } Variables & $\mathbf{X}^{\mathbf{2}}$ & $\mathbf{p}$ & risk & Lower & Upper \\
\hline Seat built in & $<.00$ & .964 & .98 & .37 & 2.58 \\
Buy with car & 1.06 & .303 & .69 & .34 & 1.40 \\
Child liked it & .58 & .446 & 1.35 & .63 & 2.90 \\
Required by law & 4.26 & .039 & 2.72 & 1.02 & 7.22 \\
Free/reduced & .76 & .383 & .72 & .35 & 1.50 \\
Educational program & .28 & .598 & 1.20 & .61 & 2.39 \\
Everyone used & .01 & .940 & 1.03 & .50 & 2.13 \\
\hline
\end{tabular}




\section{Part-Time Versus Non-Users}

Items measuring knowledge about child passenger safety, whether or not a law requiring booster seat use would increase participants' use, reasons for not using booster seats, and circumstances that would make using a booster seat easier were entered together into a model predicting the likelihood of never using a booster seat.

The results are shown in Table 14. The overall model was significant $\left(\right.$ Wald $\chi^{2}(9)=$ $17.28, \mathrm{p}=.045)$. The likelihood of never using booster seats was increased for participants who indicated that police do not enforce child safety seat laws, being in a hurry did not stop them from always using a booster seat, booster seats cost too much, and those who thought their child was too big to need a booster seat. Having their child ride with other drivers did not make using a booster seat more difficult for nonusers, who also indicated that they did not use booster seats because it was not required by law, and that using a booster seat would be easier if the law did require it.

Table 14. Association between never using booster seats and reasons for non-use

\begin{tabular}{lcccr}
\hline Variable & Estimate & Wald $\chi^{2}$ & $\mathrm{p}>\chi^{2}$ & Odds ratio \\
\hline Police do not enforce child safety seat laws & -2.09 & 3.12 & .077 & .12 \\
In a hurry & 4.12 & 8.01 & .005 & 61.56 \\
Cost too much & -4.85 & 5.89 & .015 & .01 \\
Child too big & -1.43 & 4.55 & .033 & .24 \\
Not required by law & -2.40 & 8.69 & .003 & .09 \\
Child rides with others & 1.91 & 6.12 & .013 & 6.80 \\
Seat built in & 2.46 & 3.43 & .064 & 11.66 \\
Required by law & -2.60 & 3.93 & .047 & .07 \\
\hline
\end{tabular}

Some of the odds ratio values resulting from this analysis are extreme. An inspection of the histograms presented earlier show that these extreme values are associated with variables with large differences between never and part-time users, or that had relatively small cells (i.e., smaller than 20 percent). The extreme size of the odds ratio values should be interpreted conservatively.

The model reported in Table 14 was adjusted for marital status, educational level (i.e., some college or less versus college graduate or more), number of children, income, age, and ratio of people living in the household to number of rooms in the house. Only income had a substantial effect on the model, reducing all predictors to nonsignificance with the exception of one item. After controlling for income, respondents indicating that they did not use booster seats because it was not required by law were 4.6 times more likely to be non-booster seat users than respondents who said this was not a reason. Income accounted for the other seven reasons. 


\section{Discussion}

Data were collected from a random representative sample of 350 Michigan households with 4-to-8-year-old children to identify patterns of booster seat use/nonuse, reasons for use and non-use, and factors that would make booster seat use easier. Booster seat use has not been previously studied in a state-wide representative sample. As such, this study provides unique information about factors related to parents' decisions to use booster seats. This information can be used in the development and implementation of interventions and public education programs, and booster seat distribution programs. In addition, the results strongly justify the enactment of legislation to increase the rate and consistency of booster seat use.

\section{Implications for Legislation}

The results of this study indicate that legislation is very likely to result in increased booster seat use among part-time and non-users. Four results from this study support this conclusion. First, part-time users indicated that the lack of a booster seat law in Michigan was one reason why they did not always place their children in booster seats. Second, the majority of both part-time and non-users indicated that they would be more likely to use a booster seat if it were required by law, with non-users being over three times more likely to agree with this statement than part-time users. Third, compared to always users, non-users of booster seats were nearly three times more likely to indicate that a law would make it easier for them to use booster seats. Finally, in models controlling for income level, all other predictors were reduced to non-significance, except not using booster seats because it was not required by law.

Legislation requiring parents to place their 4-to-8-year-old children in booster seats would very likely be the single most effective means of increasing the regular use of booster seats, and thereby increasing safety to children. In addition, a booster seat law would be effective across the entire population of parents with booster-seat-aged children, and not only among individuals who have higher incomes. There is, however, a belief that a booster seat law might unfairly burden people with low incomes, and the results suggest that this is a justifiable concern. Although a minority of participants (about 20 percent, see Figure 6) listed cost as a reason for not using booster seats, income was related to booster seat cost being a reason for nonuse. Follow-up analyses showed that participants with annual incomes of $\$ 20,000$ or less were 3.5 times more likely $\left(\chi^{2}=5.36, p=.021\right)$ than those with higher incomes to indicate that the cost of booster seats was a reason that they did not use them. Cost was also a significant predictor of non-use in the multivariate models. Although booster seats are inexpensive relative to infant and toddler safety seats, the potential for booster seat laws to unfairly impact the economically disadvantaged cannot be ignored, and should be addressed in legislation mandating booster seat use. There are several ways this can be achieved. For example, programs should be established that provide booster seats at reduced or no-cost to disadvantaged families. Such programs have been highly effective in distributing infant and toddler safety seats to the economically disadvantaged, and can be supported by clauses in the legislation 
stipulating that revenues generated from fines for not using booster seats can provide funds to support educational and reduced/no-cost distribution programs. Another provision that should be included in legislation mandating booster seat use is a waiver of fines if the parents acquire a booster seat, either by purchasing it or through the reduced/no-cost distribution program. Using these methods and others like them, the unfair burden of a booster seat law on economically disadvantaged people can be eliminated.

The conclusion that legislation will increase booster seat use is also supported by the effect of legislation on the use of other safety restraints. Ample evidence from other studies and populations demonstrates that the use of restraints increases sharply in response to legislation mandating their use. Legislation requiring the use of safety belts has been consistently followed by a marked increase in safety belt use. This increase is especially dramatic if the legislation allows primary enforcement of the law (Eby et al., 2000; Eby, Vivoda, Fordyce, 2002; NHTSA, 1995). Increased use has also followed the passage of laws requiring the use of infant and toddler restraints (Phelan et. al., 2002; Rock, 1996; Wagenaar, 1985).

A similar increase in booster seat use is almost certain if use is mandated, and given the preponderance of evidence of its effectiveness, primary enforcement should be a part of any booster seat law. The results of this study and others strongly indicate the need for a booster seat law to protect the health and well-being of children.

\section{Implications for Programs}

The bivariate comparisons of men and women, and part-time and non-users identified many ways in which behavioral programs could be fine-tuned. For example, men and women expressed different motivations for using booster seats. Men were more likely to focus on child control as a motive for placing their children in booster seats, while women were motivated more by concern for the children's comfort. Similarly, female part-time users were more likely than male part-time booster seat users to identify booster seat cost and being in a hurry as common reasons for not placing their child in a booster seat. Also, mistaken impressions and misinformation were evident among non-users, who were more likely than part-time users to believe that police do not enforce child safety restraint laws, and to state that booster seats are not effective in reducing injury severity. Differences such as these suggest that some programs may be more effective if they deliver messages that are sex specific, (e.g., free/reduced programs), and that non-users may benefit from educational interventions that provide them with correct information.

Although the bivariate results are interesting and can be used to good effect, the multivariate models provide a better sense of the collective effects of attitudes and opinions on booster seat use. These models were constructed using exploratory methods to identify groups of variables that combined to predict the likelihood of never using booster seats. Because they provide a collective picture of influences on booster seat use, the results can be used to identify constellations of variables that have a shared pattern of association. 
Analyses of variables answered by the entire sample (i.e., always, part-time and nonusers) indicated that the number of booster-seat-aged children in the home is related to the likelihood of booster seat use, and that as the number of children increases the likelihood of being a full-time booster seat user increases. When the model was adjusted for SES the effect of number of target children was reduced, but remained significant (Wald $\chi^{2}(1)=4.86, p=.028$ ), suggesting that SES accounted for some, but not all of the effect the number of children has on booster seat use. As with legislation requiring booster seat use, the effect of the number of children on booster seat use is also consistent across SES levels. However, booster seat cost would be an even greater concern for economically less-advantaged parents who have multiple booster-seat-eligible children. Provisions for such individuals should addressed by reduced/no-cost distribution programs.

Men who were part-time booster seat users were more likely than their female counterparts to report that they used booster seats while driving under all of the conditions measured by the interview. One potential interpretation of this sex difference is that men were more likely than women to give socially desirable responses and to inflate their report of booster seat use. However, men's responses to other items did not show evidence of social desirability, suggesting that perhaps social desirability does not explain the observed sex difference in frequency of booster seat use.

Part-time booster seat users have not been studied in detail, and it is possible that men in this population use booster seats more consistently than women. Explanations of this sex difference can only be hypothesized from the results of this study, but future research should explore several possible scenarios. For example, women transport children more often than men. As a result, women are more frequently in situations requiring booster seat and other child safety seat use, and this higher frequency of use may influence mothers' likelihood of placing their children in booster seats. Fathers may be more likely than mothers to transport children on less-frequent long trips, while mothers may be more likely to have the children in the car while running errands, or taking other frequent short trips. Because of the frequency and type of travel that they face, mothers may begin to relax booster seat rules in order to save time (e.g., trips between errands are short, and putting children in and out of safety seats takes up valuable time) and/or to avoid repeated conflict with their child. This interpretation is partially supported by the observation that women were more likely than men to say that they do not use booster seats because of being in a hurry and child refusal. Once again, these sex differences and the underlying travel patterns that might contribute to them should be considered and addressed by programs aimed at raising rates of booster seat use. 


\section{Direct Observation Versus Surveys}

Although contributing significantly to the field, this study is limited in its comparability to observational studies of child safety restraint use. Direct observation studies allow the rate of restraint use to be evaluated for a population. However, during an observational study, some drivers who rarely use restraints will happen to be using them that day, and will be counted as restraint users, while other drivers who nearly always use restraints appropriately will choose not to use them on that particular day or trip, and will be counted as non-users. Hence, observational studies of use typically provide little information about variation in individual drivers' frequencies of use or the individual characteristics that are related to use.

Discrepancies between self-reported booster seat use and ownership, and rates of observed use are not unexpected given the differing nature and purpose of these two study methods. Therefore, it is not surprising when a study that combined observational and survey methods to examine booster seat use and reasons for nonuse (Ramsey et al., 2000) found that 27.7 percent of the study participants reported that they used booster seats, yet only 10 percent were observed having their booster seat eligible child(ren) properly restrained at the time of the interview, and over 50 percent of participants who had not properly restrained their eligible children reported owning a booster seat. Discrepancies like these may arise from several sources. Drivers who are part-time booster seat users are likely to contribute to differences between observed and self-reported use. They may be observed not using a booster seat, but if asked in a survey whether or not they use booster seats, they would respond affirmatively. Additionally, parents may report that they "always" use a booster seat, when in fact, their use rate is high, but less than perfect. Finally, given western society's strong safety awareness and ethic toward the protection of children, it is likely that some of the discrepancy between observations and surveys results from social desirability and an affirmative response bias. These problems aside, booster seat use surveys remain important tools for assessing attitudes, perceptions, and motivations related to booster seat use; they provide information that is less likely to be biased by social desirability or other related confounding elements.

As the use of particular safety restraint devices becomes more common and frequency and consistency of use in a population increases, discrepancies between observed self-reported use declines. For example, NHTSA (2000) surveyed eligible participants about their use of child safety seats, and found that the majority (71 percent) of respondents reported that they always placed their referent child in a car seat. In that same year, observed national booster seat use was 68 percent for 0 -to-4year-olds (NHTSA, 2000).

While this was the first study of booster seat use based on representative data, the sample was small. Future research should target larger representative samples, and should use sampling designs that will allow important sub-samples based on variables such as race, SES, locale (rural, suburban, urban), to be studied and compared so that programs can more effectively address the needs of these populations. 


\section{Appendix A - Telephone Survey}


DATE1. (Automatically entered date of the initial call.)

(If child answers, ask to speak to an adult)

PH_REQ. I'm calling on behalf of the University of Michigan Transportation Research Institute about the booster seat use of Michigan Parents. Can you tell me if there is a child between the ages of 4 and 8 years living in your home?

$1 \quad$ Yes

$0 \quad$ No

$9 \quad$ Refused
(GO TO PARENT)

(GO TO CALL_TERM)

REQUEST. May I please talk with the parent or guardian of the 4-to-8-year-old living in your home?

$\begin{array}{lll}1 & \text { Yes } & \text { (GO TO TIME) } \\ 2 & \text { Not at home } & \text { (GO TO CALL_TERM) } \\ 3 & \text { Parent unwilling to come to the phone } & \text { (GO TO CALL_TERM) } \\ & \text { Refused } & \end{array}$

TIME. Do you have time to complete a short survey? It will not take longer than five minutes.
1 Yes
2 No, not interested in completing the survey
(GO TO QUALIFY)
3 No, does not have time right now
(GO TO CALL_TERM)
(GO TO CALL_BACK)

CALL_BACK. Is there another time that would be more convenient when I could call you back?

$$
\begin{array}{lll}
1 & \text { Yes } \quad \text { (GO TO APPT) } \\
2 & \text { No } \quad \text { (GO TO CALL_TERM) } \\
9 & \text { Refused to schedule }
\end{array}
$$

APPT. When?

DATE TIME

TARGET_P Just to make certain that I reach you when I call back, could you please tell me your first name?

\section{(GO TO LATER)}

LATER. "Thank you for your time. I am looking forward to talking with you again on <APPT_DATE> at <APPT_TIME>"

CALL_TERM. Thank you for your time. 


\section{For Call backs:}

DATE2. (Automatically entered date of the follow-up)

PH_REQ2. I'm calling on behalf of the University of Michigan Transportation Research Institute about the booster seat use of Michigan Parents. Is <TARGET_P> at home?

(If the person answering the phone is the target parent)

$\mathrm{Hi}$. We talked on the phone on <DATE1>, and had scheduled for me to call you back today. Do you have about five minutes free right now to answer a few questions?

(If the person answering the phone is not the target parent) $\mathrm{Hi}$. I'm calling on behalf of the University of Michigan Transportation Research Institute about the booster seat use of Michigan Parents. We talked on the phone on <DATE1>, and had scheduled for me to call you back today. Do you have about five minutes free right now to answer a few questions?

QUALIFY. I'm going to ask you a few questions about booster seats. Just to be sure we are talking about the same thing, a booster seat is different from other child safety seats. Infant and toddler seats are for children under age 4 and less than 40 pounds. Booster seats are for children ages 4 to 8 and over 40 pounds.

When you drive with your 4-to-8-year-old child(ren) in the car, how often do you put them in booster seats, would you say NEVER, SOME OF THE TIME, MOST OF THE TIME, or ALWAYS?

$\begin{array}{lll}1 & \text { Never } & \text { (GO TO Q1) } \\ 2 & \text { Some of the time } & \text { (GO TO Q1) } \\ 3 & \text { Most of the time } & \text { (GO TO Q1) } \\ 3 & \text { Always } & \text { (GO TO Q14) } \\ 9 & \text { Refused } & \end{array}$

Q1. How many children between 4 and 8 years of age are living in your home with you? Number of children

99 Refused

Q1A. Are you the child(ren)'s
1. Mother
2. Father
3. Step-mother
4. Step-father
5. Other adult relative
6. Other

9. $\quad$ Refused 
To simplify the remainder of the questions, I will refer to this child (these children) as the "target" child(ren).

Q2. How many booster seats do you have?

Number of booster seats (IF Q2 < Q1, THEN GO TO Q2A)

99 Refused (IF Q2 = 0, or if Q2 = Q1, THEN GO TO Q3)

Q2A. (Skip if QUALIFY = 1)

I see that you have fewer booster seats than there are target children in your home.

Which of the target children usually do not use a booster seat?

$\begin{array}{lll}1 & \text { Oldest } & \text { (GO TO Q3) } \\ 2 & \text { Youngest } & \text { (GO TO Q3) } \\ 3 & \text { Largest (i.e., tallest or heaviest) } & \text { (GO TO Q3) } \\ 4 & \text { Smallest (i.e., shortest or lightest) } & \text { (GO TO Q3) } \\ 5 & \text { Other: } & \text { (GO TO Q3) } \\ 8 & \text { if QUALIFY }=1 \text { or Q2 }=0 & \\ 9 & \text { Refused } & \end{array}$

Q3. (Skip if QUALIFY = 1)

When you are driving with the target child(ren) in the car, what percent of the time do you have the target child(ren) sit in (a) booster seat(s)?

$\%$

$\begin{array}{ll}88 & \text { if QUALIFY = } 1 \\ 99 & \text { Refused }\end{array}$

Q4. (Skip if QUALIFY = 1)

For each of the following kinds of driving would you say you USUALLY (3), SOMETIMES (2), ONCE IN A WHILE (1) or NEVER (0) have the target child(ren) ride in (a) booster seat(s).

$\begin{array}{llllllll}\text { a } & \text { Local drives (less than } 10 \text { miles). } & 0 & 1 & 2 & 3 & 8 \text { (na) } & 9 \text { (refused) } \\ \text { b } & \text { Short drives (10 to 60 miles). } & 0 & 1 & 2 & 3 & 8 \text { (na) } & 9 \text { (refused) } \\ \text { c } & \text { Long drives (more than 60 miles). } & 0 & 1 & 2 & 3 & 8 \text { (na) } & 9 \text { (refused) } \\ \text { d } & \text { Drives in rural areas. } & 0 & 1 & 2 & 3 & 8 \text { (na) } & 9 \text { (refused) } \\ \text { e } & \text { Drives in urban or suburban areas. } & 0 & 1 & 2 & 3 & 8 \text { (na) } & 9 \text { (refused) } \\ \text { f } & \text { While driving on the freeway. } & 0 & 1 & 2 & 3 & 8 \text { (na) } & 9 \text { (refused) } \\ \text { g } & \text { While driving on highways and other } & & & & & & \\ & \quad \text { non-divided roadways. } & 0 & 1 & 2 & 3 & 8 \text { (na) } & 9 \text { (refused) } \\ \text { h } & \text { While driving at night. } & 0 & 1 & 2 & 3 & 8(\mathrm{na}) & 9 \text { (refused) } \\ \text { i } & \text { While driving during the day. } & 0 & 1 & 2 & 3 & 8 \text { (na) } & 9 \text { (refused) }\end{array}$


Q5. (Skip if QUALIFY = 1)

What is the primary reason why you put your target child(ren) in (a) booster seat(s)?

NO YES NA REFUSED

$\begin{array}{llllll}\text { a } & \text { To keep them safer. } & 0 & 1 & 8 & 9 \\ \text { b } & \text { To keep them from distracting me from driving. } & 0 & 1 & 8 & 9 \\ \text { c } & \text { To control their behavior while they are in the car. } & 0 & 1 & 8 & 9 \\ \text { d } & \text { It's required by law. } & 0 & 1 & 8 & 9 \\ \text { e } & \text { So my child(ren) can see out. } & 0 & 1 & 8 & 9 \\ \text { f } & \text { So my child(ren) is (are) more comfortable. } & 0 & 1 & 8 & 9 \\ \text { g } & \text { Because I heard/read somewhere that I should. } & 0 & 1 & 8 & 9\end{array}$

If yes to Q5.g, where did you hear about it?

i. At a child seat check point or health and safety fair

ii. The hospital/doctor's office

iii. Internet

iv. Friend

v. Family member/relative

vi. TV or other media

vii. Poster/brochure

ix. Police officer

h $\quad$ To keep the shoulder strap from rubbing my child's neck.

Q6. (Skip if QUALIFY = 1)

Who usually puts the booster seat(s) into the car?

1 Self

2 Other family member

3 Friend

4 Other:

7 Don't know

8 if QUALIFY = 1

9 Refused

Q7. (Skip if QUALIFY = 1)

How did the person who puts the seat in the car learn to do it?

1 Read the instructions

$2 \quad$ Figured it out on their own

3 Other family member showed him/her

4 A friend showed him/her

5 Other

7 Don't know

8 if QUALIFY = 1

9 Refused 
Q8. (Skip if QUALIFY = 1)

How was (were) the booster seat(s) acquired?

$1 \quad$ Parent purchased it(them)

2 Other family member purchased it(them)

3 From the Hospital

4 As a gift

5 It came with the vehicle

6 Other

8 if QUALIFY = 1

9 Refused

Q9. Please answer TRUE or FALSE to each of the following statements.
a The safest place for children to sit in a car is in the back seat.
T F DK Ref.
b All children between the ages of 4 and 8 are required by law
to be in a booster seat while riding in a motor vehicle.
c Use of a booster seat can reduce the severity of injury during a motor vehicle crash.
$\begin{array}{llll}1 & 2 & 7 & 9\end{array}$
Police officers do not bother to enforce child restraint use laws. 1
d
$\begin{array}{llll}1 & 2 & 7 & 9\end{array}$
$\begin{array}{llll}1 & 2 & 7 & 9\end{array}$

(INTERVIEWER: If response to $9 \mathrm{~b}$ is true, tell the respondent that Michigan law actually only requires the use of infant and toddler child safety seats.)

Q10. Would you be more likely to use a booster seat if it were required by law?
$1 \quad$ Yes
$0 \quad$ No
$9 \quad$ Refused

Q11. When your target child(ren) is(are) not placed in (a) booster seat(s), what are the most common reasons?
a I'm in a hurry.
b My child(ren) would not use them.
c It's too much hassle strapping the kids in every time we go somewhere.
d I don't think it makes my kids safer.
e My spouse and I don't agree that it keeps our child(ren) safer.
f They cost too much.
g My child is too big and doesn't need one
$\mathrm{h} \quad$ The law doesn't require it.
i I hadn't ever heard of booster seats/ didn't know they existed.
j I don't own a booster seat.
k My child(ren) sometimes rides with someone else who does not use booster seats.

\begin{tabular}{cccc} 
NO & YES & NA & REFUSED \\
\hline 0 & 1 & 8 & 9 \\
0 & 1 & 8 & 9 \\
0 & 1 & 8 & 9 \\
0 & 1 & 8 & 9 \\
0 & 1 & 8 & 9 \\
0 & 1 & 8 & 9 \\
0 & 1 & 8 & 9 \\
0 & 1 & 8 & 9 \\
0 & 1 & 8 & 9 \\
0 & 1 & 8 & 9 \\
0 & 1 & 8 & 9 \\
& & & \\
0 & 1 & 8 & 9
\end{tabular}


Q12. What would make it easier for you to put your 4-to-8-year-old child(ren) in (a) booster seat(s) every time you take them in the car?

a If the seat were built-in the vehicle.

b If there were the option to buy a seat at the same time that the car was purchased.

\begin{tabular}{cccc} 
NO & YES & NA & REFUSED \\
\hline 0 & 1 & 8 & 9
\end{tabular}

c If my child(ren) liked sitting in a booster seat.

d If it were required by law.

e If there were a free/reduced price program.

$f$ If there were an educational program that taught parents and children together about the importance of booster seats.

g If everyone used them so that my kids wouldn't see their friends riding without them.

$\begin{array}{llll}0 & 1 & 8 & 9 \\ 0 & 1 & 8 & 9 \\ 0 & 1 & 8 & 9 \\ 0 & 1 & 8 & 9 \\ 0 & 1 & 8 & 9 \\ 0 & 1 & 8 & 9 \\ 0 & 1 & 8 & 9\end{array}$

Q13. Now I have a question about your education. What is the highest grade in school you have completed?

(INTERVIEWER: Highest grade so far.) (DO NOT READ LIST)
$1 \quad$ Less than high school graduate
2 High school or GED
3 Some college
$4 \quad$ Graduated from college (Bachelor)
5 Some graduate training or professional school with no degree
6 Earned a postgraduate degree (Masters, Doctorate, etc.)
$9 \quad$ Refused

Q14. How many rooms are there in your house, not counting walk-in closets.

99 Refused

Q15. Counting yourself, how many people are there in your family (family is defined here as parent(s) and biological and/or adopted children).

$99 \quad$ Refused

Q16. Counting all adults and children, how many people live in your home?

$99 \quad$ Refused 
Q17. What is your current marital status?

$\begin{array}{ll}1 & \text { Married } \\ 2 & \text { Divorced } \\ 3 & \text { Widow/er } \\ 4 & \text { Single } \\ 5 & \text { Partners } \\ 6 & \text { Other } \\ 9 & \text { Refused }\end{array}$

Q18. How old are you?

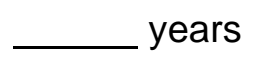

99 Refused

Q19. What is your gender?
$1 \quad$ Male
2 Female

Q20. What is your race?

1 White alone

2 Black alone

3 American Indian/Alaska Native alone

4 Asian alone

5 Hispanic/Latino alone

6 Hawaiian or Pacific Islander alone

7 Multiracial

8 Other

Q21. What is your current employment status? Are you:
1 Employed full-time
2 Employed part-time
3 A student
4 Retired
5 Housewife/Househusband
6 Other
$9 \quad$ Refused

Q22. Is your household income:

$\begin{array}{llccc} & \text { NO } & \text { YES } & \text { REFUSED } \\ \text { a } & \text { Over } \$ 5000 & 0 & 1 & 9 \\ \text { b } & \text { Over } \$ 15,000 & 0 & 1 & 9 \\ \text { c } & \text { Over } \$ 20,000 & 0 & 1 & 9 \\ \text { d } & \text { Over } \$ 25,000 & 0 & 1 & 9 \\ \text { e } & \text { Over } \$ 35,000 & 0 & 1 & 9 \\ \mathrm{f} & \text { Over } \$ 50,000 & 0 & 1 & 9\end{array}$


Q23. What kind of vehicle do you usually drive?

\begin{tabular}{ll}
1 & Passenger car \\
2 & Van/Minivan \\
3 & SUV \\
4 & Pick-up truck \\
5 & Other \\
\hline 9 & Refused
\end{tabular}

Q24. Did you visit any car dealerships during the month of October?
$1 \quad$ Yes
0 No
$9 \quad$ Refused

Q25. Since the beginning of October, have you seen any ads, local event, posters or other public information promoting booster seat use?
$1 \quad$ Yes
0 No
$9 \quad$ Refused

Q26. (Skip if Q25 is 0 [No]).

Which of the following sources of booster seat information did you see?

1. Local event sponsored by a car dealership.

2. News paper, TV or other media.

3. Posters, fliers, or brochures.

4. Other:

INT_TERM. That is all the information we need. Thank you for your time. 


\section{Acknowledgements}

This research was sponsored by the Michigan Department of Community Health $(\mathrm{MDCH})$ through a cooperative agreement with the Centers for Disease Control and Prevention (CDC), National Center for Injury Prevention and Control (NCIPC). We express our appreciation to the Michigan Child Passenger Safety Coalition that provided feedback on the development of the telephone interview items and format. Mary Chico and Renée St. Louis for reviewing this report, and to Judy Settles and Mary Chico for providing administrative support.

C. Raymond Bingham, Ph.D.

David W. Eby, Ph.D.

Heather M. Hockanson, M.A.

Arlene I. Greenspan, Dr.PH 


\section{References}

Decina LE, Knoebel KY. (1997). Child safety seat misuse patterns in four states. Accident Analysis and Prevention, 29(1), 125-132.

Durbin DR, Runge J, Mackay M, Meissner U, Pedder J, Wodzin E, Yoganandan N. (2003). Booster seat for children: Closing the gap between science and public policy in the United States. Traffic Injury Prevention, 4, 5-8.

Durbin DR, Elliot MR, Winston FK. (2003). Belt-positioning booster seats and reduction in risk of injury among children in vehicle crashes. Journal of the American Medical Association, 289(21), 2835- 2840.

Durbin DR, Kallan M, Winston FK. (2001). Trends in booster seat use among children in crashes. Pediatrics, 108, 109-112.

Ebel BE, Koepsell TD, Bennett EE, Rivara FP. (2003). Too small for a seatbelt: Predictors of booster seat use by child passengers. Pediatrics, 111, 323-327.

Eby DW, Molnar LJ, Olk ML. (2000). Trends in driver and front-right passenger safety belt use in Michigan: 1984-1998. Accident Analysis and Prevention, 32(6), 837-843.

Eby DW, Vivoda JM, Fordyce TA. (2002). The effects of standard enforcement on Michigan safety belt use. Accident Analysis and Prevention, 34(6), 815-823.

Nance ML, Lutz N, Arbogast KB, Cornejo RA, Kallan MJ, Winston FK, Durbin DR. (2004). Optimal restraint reduces the risk of abdominal injury in children involved in motor vehicle crashes. Annals of Surgery, 239(1), 127-131.

National Highway Traffic Safety Administration. (1995). The Case for Primary Enforcement of State Safety Belt Use Laws. (Report No. DOT-HS-808-257). US Department of Transportation, Washington, DC.

National Highway Traffic Safety Administration. (2000). Motor Vehicle Occupant Safety Survey, Volume 3: Child Safety Seat Report. (Report No. DOT HS 809-182). US Department of Transportation, Washington, DC.

National Highway Traffic Safety Administration. (2003a). Traffic Safety Facts: 2003 data. (Report No. DOT-HS-809-767). US Department of Transportation, Washington, DC.

National Highway Traffic Safety Administration. (2003b). Traffic safety facts: Children. (Report No. DOT-HS-809-762). US Department of Transportation, Washington, DC.

National Highway Traffic Safety Administration. (2004). Parents/caregivers report 21 percent of children ages 4 through 8 using booster seats. Traffic Safety Facts: Traffic Tech. (No. 294). US Department of Transportation, Washington, DC. 
National Highway Traffic Safety Administration. (2005). General Child Passenger Safety Seat Use Information. Accessed at: http://www.nhtsa.dot.gov/portal/site/nhtsa/template.MAXIMIZE/menuitem.9f8c7d6359e 0e9bbbf30811060008a0c/;jsessionid=CNfbFYqGRuwlYqhPyKIxX5FyX96i8BwvMiRh DGuFn3oVfj40xTHL!314358762?javax.portlet.tpst=4427b997caacf504a8bdba101891ef9a ws MX\&javax.port let.prp 4427b997caacf504a8bdba101891ef9a viewID=detail view\&javax.portlet.begCa cheTok=token\&javax.portlet.endCacheTok=token\&itemID $=061 \mathrm{fab} 6383 \mathrm{f} 62010 \mathrm{VgnVCM}$ 1000002c567798RCRD\&viewType=standard on May 20, 2005.

Phelan KJ, Khoury J, Grossman DC, Hu D, Wallace LJD, Bill N, Kalkwarf H. (2002). Pediatric motor vehicle related injuries in the Navajo Nation: the impact of the 1988 child occupant restraint laws. Injury Prevention, 8(3), 216-220.

Ramsey A, Simpson E, Rivara FP. (2000). Booster seat use and reasons for nonuse. Pediatrics, 106, 20-24.

Rock SM. (1996). Impact of the Illinois Child Passenger Protection Act: A retrospective look. Accident Analysis and Prevention, 28(4), 487-492.

Subrmanian R. (2005). Motor vehicle crashes as a leading cause of death in the United States, 2002. (Report No. DOT-HS-809-831). Washington, DC: US Department of Transportation.

Taft CH, Mickalide AD, Taft AR. (1999). Child passengers at risk in America: A national study of car seat misuse. Washington, DC: National Safe Kids.

Vaca F, Anderson CL, Agran P, Winn D, Cheng G. (2002). Child safety seat knowledge among parents utilizing emergency services in a Level I trauma center in southern California. Pediatrics, 110, 61-65.

Wagenaar AC. (1985). Mandatory child restraint laws: Impact on childhood injuries due to traffic crashes. Journal of Safety Research, 16(1), 9-21.

Winston FK, Durbin DR, Kallan MJ, Moll EK. (2000). The danger of premature graduation to seat belts for young children. Pediatrics, 105, 1179-1183. 